\title{
ARCHAEOLOGY FROM A TO Z: ABU ZARAD, AN ANCIENT TOWN IN THE HEARTLAND OF PALESTINE
}

\author{
THE ITALIAN-PALESTINIAN JOINT ARCHAEOLOGICAL PROJECT \\ AT TELL ABU ZARAD (YASUF, SALFEET, PALESTINE) - \\ FIRST SEASON OF ARCHAEOLOGICAL INVESTIGATIONS, MAY-JUNE 2015
}

Lorenzo Nigro - Chiara Fiaccavento - Sapienza University of Rome Mohammed Jaradat - Jehad Yasine - Ministry of Tourism and Antiquities of Palestine

A new agreement on cooperation for the archaeological exploration, cultural and tourist valorization of Tell Sheikh Abu Zarad, in central Palestine, has been signed in April 2015 by Rome Sapienza University and the Ministry of Tourism and Antiquities of Palestine. In May-June 2015, the first season of archaeological investigation was carried out, putting on the map this ancient mound, one of the pre-classical cities in the heartland of the country. A GIS aided survey of the tell and its immediate environs, and a systematic collection of surface pottery allowed to reconstruct its ancient landscape, and to put forward a topographic analysis of the site, as well as a provisional timeline of its occupation from the Early Bronze Age until the Ottoman Period. At a preliminary examination, Tell Abu Zarad achieved the urban status in the Middle Bronze II-III, and in Iron I-II.

Keywords: Tell Abu Zarad; Palestine; Tappuah; Middle Bronze Age; Iron Age

\section{THE AZ PROJECT FRAMEWORK}

Sapienza University of Rome and the Ministry of Tourism and Antiquities of Palestine - Dept. of Archaeology and Cultural Heritage (MOTA-DACH), in the light of a 17-years lasting fruitful cooperation in the field of archaeology and cultural heritage preservation and valorization accomplished within the Tell es-Sultan/ancient Jericho Pilot Project, signed a new agreement on cooperation for the exploration, study, scientific interpretation, and cultural and tourist valorization of Tell esh-Sheikh Abu Zarad, ${ }^{1}$ a prominent archaeological site dominating the hilly county of Salfeet, in between the villages of Yasuf and Ishqaqa, in central Palestine (fig. 1). The framework of the Project is the joined cooperation without any devolution of responsibility from the MOTA and local Authorities, in a fully post-colonialist archaeological perspective.

The AZ Archaeological Project was funded by the two joined institutions (Sapienza University and MOTA-DACH), and by the Italian Ministry of Foreign Affairs and International Cooperation (MAECI). Yasuf Municipality, in the territory of which the site is located, supported the project providing logistic help and hospitality. ${ }^{2}$

1 Even if the complete modern name of the site is Tell esh-Sheikh Abu Zarad (for the presence of the historical tomb of Sheikh Abu Zarad on its top), for the sake of brevity the form Tell Abu Zarad is preferred.

2 The Mayor of Yasuf, Mr. Hafez 'Abd el-Halim, was thoroughly helpful with the project. We also want to thank the Mayor of Salfeet, Dr. Shaher Eshtieh. 


\subsection{The Site}

The site of Tell Abu Zarad is a major mound in central Palestine at the border between Samaria and Judea, on the main north-south route (R60) connecting Tell Balata/ancient Shechem with Jerusalem/ancient Urushalimum, and Ras el-'Ain/ancient Aphek to the west with Beitin/ancient Bethel to the east (fig. 2). The nearest pre-classical site to the south-east so far known is Khirbet Seilun/ancient Shiloh, which however seems partly later in terms of general occupation in respects of $\mathrm{AZ}$.

AZ was already known from surveys in the $19^{\text {th }}$ and $20^{\text {th }}$ centuries $^{3}$ and it was convincingly identified by Father F.-M. Abel o.p. ${ }^{4}$ with Biblical Tappuah $^{5}$ (an identification which refers to a period of around a century over a life-span of around two millennia or more). A number of surveys were carried out in the region, ${ }^{6}$ and many (sometimes irreconcilable) historical conclusions were drawn after them. A systematic excavation may provide a different quality of information, thus offering a further opportunity for historical reconstruction.

The goal of the joint expedition is to explore the whole historical-archaeological parabola of this centre, a major city overlooking a hilly flourishing district of central Palestine, and to reconstruct ancient landscape, local community adaptation and organization, as well as to evaluate the contribution of AZ to the history of Palestine across all eras of history.

The first season was devoted to the study of the ancient geomorphology of the site and of its emerging archaeological features, by means of an overall survey of the nineteen sectors in which it has been subdivided (fig. 3; § 6.1.).

3 The first identification of Tell Sheikh Abu Zarad as an archaeological site worth of interest was proposed by F. de Saulcy (1865, 242), reporting «Amran-abou-Zared, à droite d'Iskakeh, un grand et beau tell couvert de ruines», with its necropolis situated on the flanks of the Ishqaqa hill itself. The site was unexpectedly missed by M.V. Guérin (1875, 162-163), who passed by Marda, Ishqaqa and Yasuf, without visiting T. Sheik Abu Zarad. He and Robison retained, erroneously, that the site of Tappuah should be identified with Khirbet 'Atuf (Zertal 2007, 110). Also C.R. Conder and H.H. Kitchener described the entire region (the northern district of Belâd al Jemaîn), but reporting Sheikh Abu Zarad only in the catalogue (Conder - Kitchener 1882, 283-288). The site was visited also by the "Shechem Regional Survey" between 1957 and 1968 (Campbell 1991, fn. 2, 98).

4 Abel 1936; 1938, 475-476. For other references to historical geography referring to Abu Zarad as biblical Tappuah see also Jenni 1958; Noth 1966, 270-273; Kallai 1986, 151-153. Also Y. Aharoni reported Tappuah (as Sheikh Abu Zarad) and the Wadi Qanah as the western limit of the northern boundary of Ephraim which separated it from Manasseh (Aharoni 1966, 236, Map 18).

5 Biblical Tappuah is mentioned seven times in Biblical narratives, five in the Book of Joshua and one in the Chronicles. The site is first mentioned in the list of the kings defeated by Joshua and the Israelites on the western side of the Jordan (Josh. 12:17), then as one of the city inherited by the tribe of Judah in the western foothills (Josh. 15:33). Recorded as marking the boundaries of the Ephraim tribe (Josh. 16:8), it is thoroughly reported as the limit between the Ephraimites (who gained Tappuah itself) and the Manassites (who obtained the land of Tappuah and the spring, En Tappuah: Josh. 17:7-8).

6 For the references regarding Abu Zarad see especially Finkelstein 1988a, ch. 4; 1988b; Finkelstein Bunimovitz - Lederman 1997, 606-610. 


\subsection{Team members and their role}

Archaeological investigations were co-directed by Prof. Lorenzo Nigro (Sapienza) and Dr. Jehad Yasine (MOTA-DACH); field directors were Dr. Chiara Fiaccavento (Sapienza) and Dr. Mohammed Jaradat (MOTA-DACH). Other members were: Pierfrancesco Izzo (GIS), Maria Tamburrini, Elena Pomar, Abdallah Shams (surveyors), Martina Di Marco, Federico Cappella, Nina Ferrante, Bassam Helmi, Mountaser Mousa, Mais Sartawy, Ahmed Dass, Faris Yasin (archaeologists), and the Architect Dr. Valeria Lollobattista.

\section{GOALS OF THE FIRST SEASON (MAY-JUNE 2015)}

The main goals of the first preliminary season were:

1. fixing the site limits, identifying its main features and surveying its topography;

2. establishing the occupational time-span of the site;

3. reconstructing the ancient landscape;

4. mapping surface finds and emerging structures in order to grasp a provisional image of underground features;

5. identifying the more suitable areas for proper excavations;

6. assuring the site the right infrastructures for a future systematical archaeological excavation, restoration and cultural valorization.

\section{SITE LIMITS AND TOPOGRAPHY}

Ancient occupation extended over 6 hectares ( 300 x $200 \mathrm{~m}$ ) covering almost completely the mound of Abu Zarad (360 x $270 \mathrm{~m}$ at the bottom, around $10 \mathrm{ha}$.), including its terraced flanks down to an almost regular bedrock cliff, which was the natural limit of the hill and was exploited as bottom of the outer city-wall from the $2^{\text {nd }}$ millennium BC. On the southeastern side the mound was connected with the nearby hill of Ishqaqa, at the top of the narrow but deep valley separating the two hills (fig. 4). On the southern side, the bedrock emerged at the bottom of the Acropolis fortification (underneath Buttress W.18), and the Outer City Wall was cut into it in order to prolong towards the south the fortified terrace existing on the western side. ${ }^{7}$ On the northern side, the hill flanks were considerably higher and deeper opening towards the wide valley of the Wadi Marda and its easternmost portion, known as the Genna'in of Yasuf, nowadays fully occupied by a beautiful olive trees grove (fig. 5) irrigated by 'Ain Yasuf Spring. An oblique south-east/north-west terrace allowed to climb over the hill and connected it with the saddle and the two springs of 'Ain Yasuf or 'Ain Tuffah, ${ }^{8}$ and 'Ain er-Raja located north-east of the tell (fig. 6). They provided a perennial source of freshwater to the city and the underlying valley of Wadi Marda. A third spring ('Ain Abu Zarad) was located at the bottom of the mound on its north-western side.

The eastern flank of the tell was roughly vertical on its top for at least $4 \mathrm{~m}$; around $10 \mathrm{~m}$ down a $2 \mathrm{~m}$ high step in the bedrock served as basis for the upper fortification line.

7 On the south-eastern slope of the site a modern road climbs it. On the west side of the latter a round water cistern was built by USAID in 2014. The cut for this building allowed to see a stratigraphic section of the site.

8 Known in the Bible as 'En Tappuah: «"The territory of Manasseh extended from Asher to Mikmethath east of Shechem. The boundary ran southward from there to include the people living at 'En Tappuah.» (Josh. 17:7). 
A second road touched the site on the southern side of the tell, climbing the hill northeast/south-west and bypassing it in direction of Salfeet (road to Jaffah/Yafo).

Emerging limestone bedrock ledges were visible to the south and on the eastern plateau (Sector III, and in Sector I underneath the maqam of the eponymous sheikh of the tell), as well as at the bottom of the Outer City Wall both on the eastern and north-western sides. The latter structure was recognizable on almost all sides of the site for an overall length of around $720 \mathrm{~m}$, with foundations laid upon the main bedrock vertical cliff all around the preserved edges of the site.

\subsection{Tell profile: the three terraces}

The archaeological site entirely occupied the hill and its topography was characterized by the three main terraces which were created by modifying the original orography of the mound (fig. 7):

a) the tell summit or northern tongue, including Sectors I-II, the maqam and Area A, which is $5 \mathrm{~m}$ higher than the upper terrace measuring $80 \mathrm{~m}$ on the east-west axis and $20 \mathrm{~m}$ on the north-south;

b) the Acropolis (including the summit), which measures $170 \mathrm{~m}$ on the east-west axis and around $90 \mathrm{~m}$ on the north-south, extended only south of the latter on Sectors VI, VII, VIII and III (with degrading north-eastern and western sides; it was bordered to the south by a second raised stones tongue stretching E-W called Sector XIX);

c) the Lower City forming a ring all around the Acropolis with a varying width (from $20 \mathrm{~m}$ to the south and in up to $40-50 \mathrm{~m}$ on the north-western terrace) at elevation 10 $\mathrm{m}$ lower than that of the summit (Sectors IX, X, XI-XIV). The Acropolis and the Lower City were separated by a 1 to $4 \mathrm{~m}$ high step, marked by a consistent wall made of large squared boulders $(0.5 \times 1 \mathrm{~m})$ visible on its southern side (W.17, W.18, W.19) and north-western sides. Several other walls (of various periods) reinforced fortifications or separated distinct sectors of the city on the western side of the Acropolis and on the northern side of the Lower City. The Outer City Wall was preserved with a height of around $5 \mathrm{~m}$ or more and frequently had a battering outer face.

\subsection{Road network and site entrance}

The main path approaching the site climbs it on the northern side, starting from the north-eastern foot of the mound and turning all around the northern slope, entering the Outer City Wall line at the north-western corner. This way is connected with the road linking the area of the springs and the Yasuf Genna'in and the tell itself. The main road bifurcated at the foot of the tell, and a second path climbed its steep eastern flank northsouth, thus approaching the saddle connecting it with the nearby hill of Ishqaqa. From this saddle, an easy access was guaranteed to the south-western Lower City. In both cases, it seems plausible that a city-gate was concealed under the ruins and paths visible nowadays.

Two main roads of the network of central Palestine passed by AZ, one running into Wadi Marda, up to Wadi Qanah, the other running on the top of the hills crests to the south, up to Salfeet, where it joined the latter in Wadi Qanah, which reached Jaffah/Yafo. 


\subsection{The necropolis}

A number of tombs were spread over the rocky crags and ridges of the mound and of the nearby hill of Ishqaqa (fig. 8). The latter, facing the site to the west, was characterized by a number of limestone ledges and terraces, as well as underlying natural caves, suitable to be easily cut and transformed into tomb chambers. Also the north-western foot of the mound presented such features, and hosted a series of tombs. In the preliminary survey of the hill of Ishqaqa and of the site flanks, also reaching the westernmost extension of the village of Yasuf, at least 13 tombs were identified, some of them already violated in antiquity and reused as rural devices (fig. 9). They belonged to several epochs mainly Middle and Late Bronze, Iron Age and Hellenistic-Roman Periods. They were cut into the bedrock with shafts or small rectangular and arched entrances. One major tomb (T2), dating from the Hellenistic Period, was characterized by a monumental entrance, a square hall with two rooms accessible through doors with decorated false-capstone (everything was carved into the bedrock).

\section{OCCUPATIONAL OUTLINE OF THE SITE}

Archaeological data concerning the site occupation in a chronological perspective were obtained by surface finds and survey, as well as by preliminary stratigraphic observations. There are, however, several historical sources which provide further information to be matched with archaeological evidence. ${ }^{9}$ They will be kept separated in the first stage of the project, as the site is untouched, and a fully unconstrained archaeological approach seems mostly required and appropriate.

Data provided by surface prospection and collection were mapped over the site topography to show the extension of human presence in different periods. The occupational range of AZ resulted from the Early Bronze Age to the Ottoman Period, i.e. from around $3000 \mathrm{BC}$ to $1900 \mathrm{AD}$, with some somewhat significant gaps in the Intermediate Bronze Age, as well as in Middle Bronze I.

Basing upon surface finds, ground and underground investigations, a provisional draft of the site occupational history may be the following:

Period I - Early Bronze Age rural (unfortified) settlement (EB II-III, 3000-2500 BC)

Period II - Intermediate Bronze Age (tombs on the nearby hills) (EB IV, 2300-2000 BC)

Period III - Middle Bronze Age fortified city (MB II-III, 1750-1550 BC)

Period IV - Late Bronze Age town (LB I-III, 1550-1200 BC)

Period V - Iron Age settlement and city (IA I-II, 1200-586 BC)

Period VI - Hellenistic-Roman garrison ( $2^{\text {nd }}$ century BC - $3^{\text {rd }}$ century AD)/ar-Raja Burj

Period VII - Byzantine installation $\left(4^{\text {th }}-7^{\text {th }}\right.$ century AD)

Period VIII - Islamic rural installation (Umayyad, Ayyubid, Mamluk, $7^{\text {th }}-16^{\text {th }}$ century AD)

Period IX - Ottoman monument $\left(17^{\text {th }}\right.$ - early $20^{\text {th }}$ century AD)

Period X $-20^{\text {th }}$ century (before Second World War).

9 Abel 1936; Abel 1938, 475-476. 
The site extension, features and significance varied consistently through time, and at a general reconstruction, up to now (before systematic excavations), can be only hypothesized stating that in late periods (VI-VIII) it was restricted to the Acropolis and its summit, while in periods III-V it apparently extended over the whole mound. The extension of Period I occupation could not be determined. Materials of Late Periods were also retrieved in the nearby necropolis of Ishqaqa.

It seems too early to draw out any historical consideration basing on the above illustrated preliminary timeline of the site. At least ten years of systematic excavations are needed to allow any further insight into the very history of AZ and its contribution to that of Palestine and, possibly, of the whole Levant.

\section{TELL ABU ZARAD AND ITS LANDSCAPE}

The geomorphological setting of the site is crucial for the understanding of its role in antiquity. The hill is the highest pick of a limestone range gradually degrading in southwest direction which borders to the south the wide and gently sloping valley of Wadi Marda, turning progressively towards the north-west where it flew into Wadi Qanah (the river flowing towards south-west reaching Jaffah/Yafo). Towards the east, conversely, the mound of Abu Zarad dominates the crossroad of the north-south main road from Tell Balata/Shechem to Jerusalem, with the east-west track climbing up from the Jordan Valley along wadis and reaching from the one side Shiloh and Bethel, and from the other straight the Jordan. The $360^{\circ}$ panorama visible from the site summit in a radius of at least $20 \mathrm{Km}$, made AZ a pivotal centre at the border between Samaria and Judea. Tell Abu Zarad assured a view up to Mount Garizim and Tell Balata to the north, to the Aqraba pass to the east, leading to the Jordan Valley, and to Ras el-'Ain/ancient Aphek to the west up to Jaffah and the Mediterranean sea. Wadi Aramiyeh and the road to Khirbet Seilun/ancient Shiloh were also watched from AZ. All major ancient tracks and roads of central Palestine were under the site visual control, as well as the main road to the west running aside it. ${ }^{10}$

\subsection{The three springs ('Ain Yasuf, 'Ain er-Raja and 'Ain Abu Zarad) and the tower (er-} Raja Burj)

The hill itself, around $360 \times 270 \mathrm{~m}$ at the bottom (ca. 10 ha.), consisted of a solid sedimentary limestone cliff with degrading terraces (3-4 m high) of rock banks wisely exploited by the inhabitants of the city erected upon it. The main limestone layer, $3 \mathrm{~m}$ high, emerging on the mound flanks as a vertical spur or step, concealed at its basis the phreatic aquifer which sprung out in three spots, making the $\mathrm{AZ}$ environment an utmost favorable place to human settlement.

All springs were aligned at the bottom of the rocky step, on a line starting from the north-eastern corner of the mound and stretching underneath the northern edge of the modern village of Yasuf. The most generous one was 'Ain Yasuf, located around $700 \mathrm{~m}$ north-east of Abu Zarad at the easternmost head of Wadi Marda (fig. 10). This spring (also

10 The so-called "Tappuah junction" is still today a major crossroad of the country, where Israeli settlers and Palestinian inhabitants of the provinces of Nablus, Ramallah and Salfeet come necessarily across. 
called in antiquity 'Ain Tuffah) is a prominent feature of the local landscape. Crystalline water springs out from a crack of the mountain flank at the bottom of a rocky cliff at least 6 $\mathrm{m}$ high, bringing flourishing life in relatively small yard, where fruit-trees groves and orchards are still today intensively cultivated, known as the Yasuf Genna'in ("garden” or "paradise"). The water flow is around 50 liters per minute, and it was channeled into canals crossing the small valley, while some streams were directed to a water reservoir located at the north-eastern foot of the hill. The gentler slopes of this valley in respect of the surrounding hills made it a generously productive and well protected ecological niche, where also numerous domesticated and wild animals lived (including horses, donkeys, and cattle). ${ }^{11}$

A second flow of fresh water ('Ain er-Raja) was caught by the inhabitants of AZ around midway from the latter, $350 \mathrm{~m}$ far from the north-eastern corner of the tell, by cutting the same bedrock from where the Yasuf spring is fed. Water flow was somewhat weaker but it filled up a stone-built well, and apparently was channeled towards the city water system. The spring construction was inserted into the rock fissure ending at the bottom with a capstone protecting the outflowing of water (fig. 11).

Around $50 \mathrm{~m}$ to the east of 'Ain er-Raja, the ruins of a major tower made of carefully dressed limestone boulders was discovered (fig. 12): the original building of er-Raja Burj dates from the Hellenistic and Roman times (as suggested by surface residual pottery, including terra sigillata, and Hellenistic amphorae), ${ }^{12}$ but it was reused in later periods. Underneath the tower's north corner a pit-hole is the entrance to an underlying cave (fig. 13) where healing waters spill off, apparently also connected to the same aquifer of 'Ain Yasuf and 'Ain er-Raja. In the Ottoman Period the Tower structures were incorporated into a house of the village of Yasuf.

A third spring ('Ain Abu Zarad) was available for the inhabitants of the city at the mound north-western foot, where the underground water again came out. Moreover, a well on the Acropolis (We.2) in the north-east sector (III) of the site reached the same phreatic aquifer and until forty years ago used to be filled up by waters in springtime.

Fresh-water availability, fertile land in the immediate surroundings, and the tell dominant position, which overlooked the crossroad of the north-south and east-west tracks of inner Palestine, were the main characteristics of the ancient city arisen on Tell Abu Zarad.

\subsection{Ancient landscape of Abu Zarad}

The reconstruction of ancient landscape of AZ is not easy: nowadays the hills flanks are terraced and occupied by almond and olive trees and yards bordered by stone walls with round trunk-conic towers (at least 13 of them were attributed to the AZ district by previous surveys), which are typical of the landscape of Palestine. How it looked like in pre-classical

11 Albright 1925, 7-8.

12 The Arabic term burj derives from the Greek pyrgos or late Latin burgus. This type of towers has been attributed to the Crusader period by D. Pringle (1994, 335-336), even if he stated that its origin can, in many cases, be assigned to previous periods, lately reorganized and reused (as in the renowned example of the socalled "Tower of David" in Jerusalem, originally built by King Herod the Great in 37-34 BC). 
and classical antiquity has to be fully reconstructed. Settlement studies and a consolidated scholarly tradition attributed to the Iron Age the regularizing of Palestinian hills by means of terrace walls, in order to gain cultivable land and to avoid erosion provoked by rainwater, the creation of cultivated fields and the erection of conic watchtowers, which trough centuries became a typical feature of the rural landscape of the country and a symbol of Palestinian vernacular architecture. Landscape transformation due to human activities, however, in the central hill region may date back even to the Early and Middle Bronze Ages. ${ }^{13}$ The need of cultivable land was not particularly pressing at AZ, where gently sloping Wadi Marda provided a wide and fertile agricultural estate, an ecological niche which supported through following epochs the life (fig. 14). Nonetheless, landscape shaping was soon practiced by the inhabitants of AZ, who cut canals and regularized emerging bedrock both for catching freshwater and setting rural devices. Furthermore, limestone cliffs and spurs were exploited for defensive purposes as solid foundations for defensive works all around the tell. This was basically due to the fact that AZ arisen as a top-hill site, entirely occupying the summit of the mound. Emerging bedrock terraces and sloping flanks of the mound were thus strongly affected by human impact during history, which adapted it to defensive and habitat needs.

Local flora was characterized by series of trees typical of the Mediterranean basin: holly oak (Quercus ilex), cypress (Cupressus sempervirens), wild olive and fig, the latter especially concentrated in the springs' vicinity or by cisterns and wells, which were numerous on the site and around it. Holly oak provided a powerful combustible and robust wood for building, cypress long beams and resin, olive tree a strong wood for furniture and inlays, while fig, of course, its fruits. Other plants populating the site environment were typical Palestinian bushy trees (tamarisk and lentisk) used especially in domestic and rural architecture. Hay and straw were largely available in the AZ catchment area, at a mean altitude of 550-650 m a.s.l. They provided feeding for household and transport animals, basically donkeys, but also horses and cows. In the scrub on the hillsides also other animals lived, like the wild boar, foxes, porcupines, hedgehogs, wolves, and a variety of birds.

Anthropic action introduced a number of plants connected with horticulture (lentils, peas, chickpeas, broad beans, and beans), and fruit plants: almonds, pomegranate and medlar trees, as well as, above all, grafted olive tree and grape, which progressively and radically modified AZ's environment. To establish a chronology in this phenomenon is another task of the expedition. Cultivation terraces were built on the site slopes apparently from the Hellenistic Period onwards, while before main interventions on the mound flanks were connected with its fortification in the Middle Bronze Age by means of stone ramparts and bastions. These terraces became a typical feature of the landscape and were connected with rainwater collection and spring water management by means of drains and canals. The overall aspect of the upper eastern part of Wadi Marda was that of a flourishing garden (Genna'in), and it is astonishingly preserved still today (fig. 15).

13 Sayej 1999 


\section{THE TOPOGRAPHY OF THE SITE}

A detailed survey of the site was carried out by subdividing it into nineteen sectors, named with Roman numbers (I-XIX) from the summit of the Acropolis, where the maqam of the sheikh lies, all around the site counterclockwise. The snail-shaped mound was, thus, prospected by a team of nine archaeologists plus one architect, a GIS expert and three surveyors with the help of a GPS and a GPS Total Station. All emerging structures or noteworthy features were recorded as well as surface finds.

\subsection{Subdivision into sectors (fig. 3)}

Sector I includes the maqam, i.e. a square monument surmounted by an irregular dome, flanked to the northwest by a couple of rooms opened with a porch to the east (fig. 16). The maqam rests upon a built up substructure (2.5 m high), possibly the rebuilding of a preexisting building of the Late Ottoman Period, and its shape nowadays dominates the surrounding landscape. The small mound of stones upon which the maqam was erected is characterized on the northern side by the presence of swollen big slabs, and it may have hosted a major building of previous periods.

Sector II (Area A) is located just west of the maqam and it extends westwards for more than $80 \mathrm{~m}$. It is roughly $20 \mathrm{~m}$ wide on the north-south axis. It consists of a huge heap of stones, which raises $5 \mathrm{~m}$ up over the elevation of the nearby Acropolis, and around $10 \mathrm{~m}$ over the northern lower city, towards which it is separated by a steep slope bordered at the basis by limestone boulders. Over this summit, called Area A, the remains of the northern wall (W.42) of a building were uncovered, as well as two or three small chambers (L.41) possibly belonged to it (fig. 17). The date of such building was not established so far. At the junction between the maqam basement and Area A, the elongated heap of stones, a round structure, a cistern (Well 1), was also detected, with a diameter of around $3 \mathrm{~m}$, possibly to be dated to the Hellenistic Period (fig. 16, middle).

Sector III includes the north-eastern part of the Acropolis, gently degrading eastwards. The most prominent emerging feature is a well (Well 2) connected with the phreatic aquifer at the foot of the tell. This installation was preliminarily cleaned in this season (fig. 18).

Sector IV occupies the whole northern part of the so-called lower city, underneath the maqam and adjacent Sector II. There are no emerging walls in this area, which is nowadays densely populated of almond trees. A radial wall made of fieldstones stretches from the north-eastern corner of the maqam towards NE and it separates lower Sector IV from Sector III.

Sector V is the NW corner of the lower terrace. On its northern and western sides it is bordered by a line of terrace or defensive walls, which especially reinforce the NW corner of the city. To the south, it is separated by a $1.5 \mathrm{~m}$ high wall from Sector VI, which occupies the whole south-western portion of the Acropolis.

Sector VI is the largest and flattest portion of the Acropolis, bordered to the north by the high mound of the summit, to the south by wall W.19 and W.17 and to the west by walls W.29 and W.39. In this area a series of installations were identified: to the east wall W.5 with attached Well 4 (fig. 19); wall W.6 stretching N-S for at least $15 \mathrm{~m}$ and Well 7 just west of the latter. Another well (Well 11) was uncovered in the south-eastern area of the sector, having been partly excavated by looters. 
Sector VII is the central part of the Acropolis, around $0.5 \mathrm{~m}$ higher than the side sectors. It has roughly a rectangular shape and it is bordered to the south by the second mound again consisting of a heap of stones resulting from the collapse of some major buildings (called Sector XIX; fig. 20). West of the small mound in a flat area a well and a cistern were uncovered (Well 9), while another well was visible in the heap of stones just southwest of the summit of the small mound. The northern limit of Sector VII was mainly Sector I. A step of around $1.5 \mathrm{~m}$ separates this area of the acropolis from the surrounding Lower City to the east, with Sectors VIII and III.

Sector VIII occupies the south-eastern quarter of the Lower City, a $50 \mathrm{~m}$ wide and flat area, where a modern iron pillar has been erected. Along the western limit of Sector VIII, at the edge between it and Sector VII, a slab paving (L.12) was uncovered, belonging to open space facing a major building (fig. 21). The date of such structures cannot be fixed before excavations.

Sector IX lies east and below of Sector VIII. It has a crescentic shape, incorporating a spur protruding further towards the east, possibly the remains of a major defensive work. The slope towards the south east, terraced in antiquity (after the urban phase of life of the site had ceased) was named Sector IX South. In this sector an E-W oriented wall (W.13) made of well-dressed stones was uncovered (fig. 22).

Sector $\mathrm{X}$ is a ring shaped area, starting from the eastern side of the site and continuing all around it counterclockwise, forming what has been labelled the "Lower City" (fig. 7), i.e. a berm or terrace $15-20 \mathrm{~m}$ wide, which on the north-western and western sides of the mound was delimited by bedrock step and a superimposed stone wall.

Below this stepped ring, the mound flanks were terraced in different ways according to their displacement. Sector XI on the north-eastern side, included the ramp ascending the site E-W, up to a widened terrace (Sector XII) where the outer fortification of the main NW gate possibly stood (fig. 23). It was followed by Sector XIII, a flat and regular strip along the western side of the site, where the western gate (Sector X SW) to the Acropolis was opened with its alleged fortifications (Area C).

Sector XIV is the continuation of this terrace south of wall Tower W.25+W.27. Here the fortification wall of the Acropolis is visible made of big rectangular boulders: W.17+W.19+W.18 (fig. 24). The terrace of the Lower city is here supported by the Outer Wall (W.32).

Sector $\mathrm{XV}$ is a rectangular slope underneath the city protruding fortifications on the eastern side, the foot of the tell on this side.

Sectors XVI, XVII, XVIII are the sloping foot of the mound, underneath the city outer fortifications; at different spots they included other fence walls of later periods, and even transversal walls subdividing land estates belonging to different families.

Sector XIX is the second small mound of stones raising at least $3 \mathrm{~m}$ over the top of the inner ground of the Acropolis, bordering it on the south-eastern side, and possibly originated by the collapse of some major buildings overlooking the Salfeet road from that spot, crossing the hills edge just south. 


\subsection{Major architectural features in Areas A, B, and $C$}

Area A was located on the tell summit and in the surroundings of the maqam, stretching east-west over the small mound made of collapsed stones which comprises Sectors I and II. Here, some structures were identified on the central (W.42) and western (L.41) top of the stones mound, in between it and the maqam (fig. 16).

Area B is at the eastern edge of the tell, on the line of the Outer Wall (here named wall W.16) which has a preserved height of more than $10 \mathrm{~m}$ over the main bedrock terrace emerging on the flank of the mound (fig. 25). A major bastion, called W.43 abuts from the line of the fortification (fig. 26), and, at its foot, an external structure (W.15+W.45), with a varying width $(1.5-3 \mathrm{~m})$ and orientation forms a sort of advanced defense line, running on the edge of a main bedrock step (fig. 27). On top of the bastion, an emerging wall (W.3) possibly belonged to a major building.

Area $\mathrm{C}$ was located across the emerging western defense system of the Acropolis. Some major architectural features were visible at the south-western corner of the Acropolis. A series of protruding structures were part of a corner fortification or an inner gate. Actually, three lines of walls could be identified, which follow the tell contour (fig. 28). Wall W.29 was preserved with a height of $1.5 \mathrm{~m}$. It corresponds to the Acropolis edge (fig. 29). A ramp or a subsided portion was visible roughly at the middle of the structure, which continued to the north as wall W.39. W.29 was flanked to the south by a major structure built of roughly dressed limestone blocks $(0.5 \times 1 \mathrm{~m})$, called W.17, which runs towards south-east at the foot of the first step of the Acropolis and is linked to W.19. An emerging foundation (W.31) $2 \mathrm{~m}$ far from the foot of W.29+W.39 possibly is the spoiled continuation of W.17+W.19. A further step was marked by ramp-wall W.27 and W.30 to the north, visible some 4 to $7 \mathrm{~m}$ to the west, which was characterized by a protruding massive stone foundation with rounded corners, called Tower W.25 (figs. 30-31). A passageway runs between wall W.30 and Tower W.25; a diagonal structure wall W.40, leaning on W.30, might be interpreted as part of a gate.

A third step of the site on its western edge, which was represented by two interconnected structures, W.32 and W.34, with a height of more than $3 \mathrm{~m}$, is the Middle Bronze Age Outer Wall (fig. 32).

\section{MAPPING OCCUPATION ON THE BASIS OF POTTERY}

Pottery was systematically collected from the tell surface and it was successively selected and classified. GIS aided study helped in calibrating data. At the end of this process, a map showing the spatial distribution by periods over the nineteen sectors has been drawn (fig. 33). The overall spreading of pottery diagnostic fragments by periods provides a closer insight into the site. The most largely attested to period is the Middle Bronze II-III, spread over the whole mound. Late Bronze is present in the Upper City, but probably partially removed by following periods. Iron Age (I and II) is found both in the Upper and Lower City, with a major concentration to the east. Hellenistic, Roman, Byzantine and Islamic periods are mainly concentrated on the Acropolis and in Sectors VIIVIII, and at the eastern foot of the tell (in direction of the ar-Raja Burj). Early Bronze Age sparse pottery sherds were collected on the western flanks of the tell. 


\section{POTTERY FINDS: PERIODS AND DESCRIPTION}

Pottery fragments collected belonged to different classes with an unbalanced attestation depending of the coefficient of persistency of each ceramic type. The selection was based on the representativeness of the pieces, excluding those ones too much worn to supply reliable information about their chronological period or original shape. Nevertheless, all the unselected fragments have been stored in the MOTA storerooms, for future statistical analyses.

The pottery sample consists of (fig. 34): Early Bronze sherds (1.3\%); Middle Bronze (33\%); Late Bronze (3.5\%); Iron Age I (6.9\%); Iron Age II (32\%); Persian (1.5\%); Hellenistic (6.9\%); Roman (5.9\%); Byzantine (4\%); Islamic (3.5\%); Mameluk (1.5\%).

The main occupational periods are the Middle Bronze and the Iron Age, even if the great variety of attested epochs well highlights the strategic importance of the site along the ages. This paragraph deals mainly with these two periods, setting the repertory within the ceramic horizon of the central Palestinian hills. The nature of the sample is strongly unbalanced toward storage ware, a common trait of surveys' results, depending on the physical characteristics of preservation ware which better resists on surface. Comparisons for AZ types in these two periods are retraceable in the assemblages of the main sites of the central hill country and the lower Jordan Valley (synthetically listed in footnotes when available): for the Middle Bronze Tell Balata/Shechem, Khirbet Seilun/Shiloh, Beitin/Bethel and el-Jib/Gibeon; for the Iron Age I Khirbet Seilun/Shiloh, 'Izbet Șarțah, ElAhwat, Mount Ebal, Beitin/Bethel, Khirbet Dawwara, Ras el-'Ain/Aphek and Dothan; and for the Iron Age II Samaria, Tell el-Farah N, Dothan, Beitin/Bethel and Tell esSultan/Jericho.

The illustration of post-Iron Age pottery is provisional and will be expanded in future reports, along with a fine-tuning or realignments of pottery types of each period.

\subsection{Early Bronze Age (fig. 35)}

The Early Bronze fragments compose a very small sample: a simple hemispherical bowl with slightly flattened rim (fig. 35:1) and a couple of the commonest diagnostic form of the EB, two hole-mouth jars (fig. 35:3-4). They are not really representative of a specific subperiod, even if their fabric, plus a fragmentary pushed-up ledge handle (fig. 35:6) and a thin wall with a simple painted decoration (fig. 35:2) seem to possibly assign the scarce repertory to the EB II. ${ }^{14}$ The last fragment is a flattened and incised band, rope-like decoration of a storage pithos (fig. 35:5).

\subsection{Middle Bronze Age (figs. 36-37)}

The Middle Bronze II-III is well represented, being probably the most important occupational period of the site. It is illustrated mainly in storage ware with a few fragments of simple ware and only two fragments of White Slip production, plus a fragmentary lamp with sinuous sides (fig. 36:3). The White Slip pieces are one jug with everted rim and

14 For a general assessment of the occupational trends of this region during the Early Bronze Age see Finkelstein - Gophna 1993. 
straight neck (fig. 36:2) and one jar with thick everted rim (fig. 36:1). Simple bowls with incurved $\operatorname{rim}^{15}$ (fig. 36:4-6) and one typical bowl with sharply out-curved rim and high Sshaped profile (fig. 36:7), ${ }^{16}$ three platter-bowls ${ }^{17}$ (fig. 36:9-11), one large bowl with triangular everted rim ${ }^{18}$ (fig. 36:12), and one mortar (fig. 36:13), plus several small everted jars (fig. 37:1-2) and ring-bases ${ }^{19}$ (fig. 36:14-16) (of bowls or jugs) compose the Simple Ware repertory. The Storage Ware is the best represented part of the ceramic repertoire, since the highest number of $\mathrm{MB}$ fragments are ascribable to medium and big size preservation jars, with the characteristic turned out and externally ridged rim (fig. 37:313), ${ }^{20}$ with a fragment of wall bearing the classic incised herring-bone decoration ${ }^{21}$ (fig. 37:14) and a wall with subtle horizontal lines on two bands (fig. 37:15). ${ }^{22}$

\subsection{Iron Age I (fig. 38)}

The Iron Age I is characterized by a limited repertoire, both for the scarcity of recognizable pieces preserved in surface, and maybe also for the general reduced number of utilitarian shapes employed in the Hill Country, comprising mainly cooking pots, storage jars and pithoi. ${ }^{23}$ Three simple jugs compose the Simple Ware repertory: one jug has a narrow ridged rim (fig. 38:1), ${ }^{24}$ the other a rounded and internally swollen rim with handle directly attached on it (fig. 38:2) ${ }^{25}$ and the third a simple flaring rim with circular mark on the handle departing from it (fig. 38:3). ${ }^{26}$ Jars and pithoi (in Storage Ware) show three kinds of rim: a thickened folded or everted rim, with short neck (fig. 38:4-5); a thick round rim with short neck (fig. 38:10); ${ }^{27}$ a plain vertical rim (fig. 38:7, 9). ${ }^{28}$ Between those belonging to the first type, two pieces show a "collar" (actually a protruding ridge) at the

15 Fig. 36:4-6, 8 (respectively Kenyon - Holland 1982, figs. 120:3; 105:6; 104:12; 105:13)

16 The carinated bowls are attested in all the contexts of the Central Hills (and well beyond), see for instance: Pritchard 1963, fig. 32:16; Cole 1965, pl. XXVI:c; Buhl - Holm-Nielsen 1969, pl. 18:231.

17 Platter-bowl with inverted pointed rim: fig. 37:9 (Pritchard 1963, fig. 32:6; Kelso 1968, pl. 50:15). Platterbowl thickened and upright internally: fig. 37:10 (Cole 1965, pl. VII:b; Kelso 1968, figs. 28:1; 46:1; Bunimovitz - Finkelstein 1993, fig. 6.10:2). Platter-bowl with rounded inverted rim: fig. 37:11 (Cole 1965, pl. XVI).

18 Cole 1965, pl. XI:d.

19 Several more ring bases have been retrieved but here a small sample of three pieces is represented. High pedestal bases are scarce, generally belonging to the last MB phase and to the LB.

20 Cole 1965, pls. LVII, LXIII; Kelso 1968, pl. 49:3,5-6; Kenyon - Holland 1982, figs. 128-131; Bunimovitz Finkelstein 1993, fig. $6.7 \mathrm{ff}$.

21 Kelso 1968, pl. 52:1; Kenyon - Holland 1982, fig. 113:2,7; Bunimovitz - Finkelstein 1993, fig. 6.7:239.

22 This type of decoration vastly attested in the EB IV repertory is sometimes attested also on MB pieces. Cole 1965, pl. LXVIII:c.

23 Mazar 2015, 8-9.

24 Buhl - Holm-Nielsen 1969, pl. 18:242.

25 Bunimovitz - Finkelstein 1993, fig. 6.57:13.

26 Be’eri - Cohen 2012, fig. 12.12:7.

27 Zertal 1986-1987, fig. 14:8; Finkelstein 1990, fig. 16:7-10.

28 Zertal 1986-1987, fig. 13:8; Bunimovitz - Finkelstein 1993, figs. 6.48:4; 6.53:5; Master 2005a, fig. 9.25:1-2. 
base of the neck (fig. 38:4, 8), hallmark of the IA I in the Hill Country, and elsewhere. ${ }^{29}$ It is part of the storage ware an incised handle of a jar too, with a vertical deep line incised (fig. 38:6). ${ }^{30}$ Cooking pots rims too do have many different shapes: in the sample are attested a lengthened triangle rim, with a straight interior (fig. 38:11), ${ }^{31}$ a tapered and inward bow rim (fig. 38:15), and a thickened ridged rim (fig. 38:12), ${ }^{32}$ with the handles attached on or immediately under it. Cooking jugs show a plain rim (usually gently concave on the interior) and a smaller diameter of the mouth, with a single handle attached on only one side of the rim (fig. 38:13-14). ${ }^{33}$ The repertory may be attributed to Iron Age IB.

\subsection{Iron Age II (figs. 39-41)}

The development of forms in Iron Age II follows the same pattern as that in other northern regions, towards more standardization in shapes and surface's treatments. The Red Slip pieces are bowls with simple, upright ${ }^{34}$ (fig. 39:1-2), projecting diagonally in, ${ }^{35}$ or projecting in and out, rims (fig. 39:3-6); ${ }^{36}$ kraters with rim curved obliquely out and lip projecting in (fig. 39:7, 9-10); ${ }^{37}$ jugs with vertical neck and double rim (fig. 39:8). ${ }^{38}$ The slip is dark red (2.5YR5/8 Red) and it occurs outside, along with the burnishing, or both outside and inside on the open shapes. In Simple Ware a round-sided bowl with folded rim (fig. 40:1) ${ }^{39}$ and two kraters with hammerhead rims (fig. 40:2-3) compose the small repertory of the open shapes, while numerous closed shapes are attested: mainly jars with double rim (fig. 40:4-7) ${ }^{40}$ and jugs with simple everted rim and handle attached on it (fig. 40:8-15). ${ }^{41}$ The Storage Ware repertory includes, along with a pair of hole-mouth jars, with flattened (fig. 41:1) ${ }^{42}$ or slightly groomed rim (fig. 41:2), ${ }^{43}$ jars with vertical neck and

29 Originally identified by W.F. Albright (1934, 12-13) and at length considered the "type-fossil” for the Israelite presence in the Iron I settlements in the Central Hill Country, the collared-rim jars (or pithoi) are not strongly ascribable to a specific ethnic attribution, seen their presence in Canaanite contexts (Coastal Plain, Jezreel Valley, Beth Shean, Tell es-Sa'idiyeh) since the end of the Late Bronze Age (Esse 1991; Mazar 2015, 13-14, with previous references). Kelso 1968, pl. 56:9,12; Master 2005a, fig. 9.25:5.

30 Zertal 1986-1987, fig. 20, 136-137; Bunimovitz - Finkelstein 1993, fig. 6.61:25; Finkelstein - Bunimovitz Lederman 1997, fig. 8.240:33-34, 162.

31 Kelso 1968, pl. 57:10; Mazar 1981, fig. 7:9,12; Gadot 2009, fig. 8.7:4, 215; Mazar 2015, pl. 1.1.11:5, 12.

32 Finkelstein 1986, fig. 18:15.

33 Finkelstein 1986, fig. 19:8; Gadot 2009, fig. 8.9:3 (defined as jug).

34 In the Samaria region, simple and upright rims of bowls and plates are more attested in the first part of the Iron Age II (A-B), whereas the folded, flanged and hammerhead rims belong generally to IA IIC (see Tappy 2015a, pl. 2.3.1:1-13; 2015b, pl. 3.2.1:1-12). Crowfoot - Crowfoot - Kenyon 1957, fig. 6:6.

35 Kelso 1968, pl. 62:17; Chambon 1984, pl. 56:11

36 Crowfoot - Crowfoot - Kenyon 1957, fig. 11:2; Kenyon - Holland 1982, figs. 200:4-5,13; 201; Chambon 1984, pl. 56:9, 19-20.

37 Kelso 1968, pl. 62:15; Kenyon - Holland 1982, fig. 203:4.

38 Kenyon - Holland 1982, fig. 209:19.

39 Kelso 1968, pls. 62:4; 64:1-2.

40 Kelso 1968, pl. 67:12; Chambon 1984, pl. 45:4-5; Master 2005b, fig. 10.55:1-3.

41 Chambon 1984, pl. 48.

42 Crowfoot - Crowfoot - Kenyon 1957, fig. 6:22; Mazar 1990, fig. 11:15.

43 This type of rim is generally more attested, in the Samaria region, towards the final part of the Iron Age: see Tappy 2015b, 330; Kelso 1968, pl. 66:5. 
simple, or thickened and slightly everted rim (fig. 41:3-6). ${ }^{44}$ In Cooking Ware, abundant are the pots with thickened and externally grooved rim (fig. 41:7-13), ${ }^{45}$ sometimes also with handles attached on it. The repertory seems to cover all the Iron Age II sub-periods, with a subtle preponderance of IA IIC.

\subsection{Persian, Hellenistic, Roman, Byzantine and Islamic (fig. 42)}

The Persian Period is attested by a single certain fragment: a rim (?) with a decoration in form of triangular wedges (fig. 42:1), which is common in Persian times and date to the late $6^{\text {th }}$-late $4^{\text {th }}$ centuries. ${ }^{46}$ The Hellenistic era is well represented on the site with four saucers: one vessel with over-hanging rim and black slip (fig. 42:2), ${ }^{47}$ one red slip triangular rim (fig. 42:3) and one dark red ring base, with rouletted motif on the interior (fig. 42:4); ${ }^{48}$ the last is unslipped with simple everted rim (fig. 42:5). ${ }^{49}$ Simple Ware presents jars with vertical or splayed rim and in Storage Ware handles with indented section (fig. 42:6-13).

Roman terra sigillata was found scattered on the collapsed structures of the ar-Raja Burj. A few fragments of Byzantine period, with deep corrugation outside and blackish colour (fig. 42:14-17), have retrieved along with a couple of Mamluk's fragments: a jar with double slightly everted massive rim shows the typical Hand-Made Geometric Painted ware (HMGP), with black designs painted on over a whitish slip (fig. 42:18). ${ }^{50}$

\section{FIRST STEPS TOWARDS A DEEPER UNDERSTANDING OF THE SITE}

The accurate survey conducted in May-June 2015 and the descended studies of AZ are the needed base to launch the excavation project. They permitted the individuation of the excavation areas and a first appraisal of the topography, emerging architecture and material culture of the site. The places chosen to be investigated first are: Area A, the upper point of the Acropolis, west to the maqam; Area $\mathrm{C}$, where the number of emerging walls over multiple terraces promisingly envisages a long chronological stratification. The first squares have thus been set on the ground in Area A in October-November 2015, for the second season on the field, the results of which will be published in the next report on the Abu Zarad Project.

Archaeological work will be coupled with a full rehabilitation of the site to become in the future a naturalistic-archaeological park within the Municipality of Yasuf under the

44 Crowfoot - Crowfoot - Kenyon 1957, fig. 11:27; Kelso 1968, pl. 66:2.

45 Crowfoot - Crowfoot - Kenyon 1957, fig. 6:10; Kelso 1968, pl. 65:1-3, 6; Chambon 1984: pl. 53:5; Mazar 1990 fig. 11:13.

46 Stern 2015, 578

47 Berlin 2015, 634, pl. 6.1.2:6.

48 Berlin 2015, 634, pl. 6.1.2:12.

49 The decoration of rouletted motif on the interior of the bowls mainly occurs in imported Attic pottery types, already in the Persian period, or derives from Greek prototypes (see Berlin 2015, 633-634, pl. 6.1.1:3-4; Rosenthal-Heginbottom 2015, 680, pl. 6.2.5:23).

50 Master 2005c, 154, fig. 13.16:7-15; Gabrieli- Ben-Shlomo - Walker 2014 
aegis of the Province of Salfeet. This will contribute to protect and valorize one major cultural and archaeological resource of this central region of Palestine.

\title{
REFERENCES
}

\author{
ABEL, F.-M. \\ 1936 V. Chronique - Tappouah: Revue Biblique 45/1 (1936), pp. 103-112. \\ 1938 Géographie de la Palestine, Tome II: Géographie Politique. Les Villes, Paris 1938. \\ AHARONI, Y. \\ 1966 The Land of the Bible: A Historical Geography, London 1966. \\ ALBRIGHT, W.F. \\ 1925 Bronze Age Mounds of Northern Palestine and the Hauran: The Spring Trip of the School \\ in Jerusalem: Bulletin of the American School of Oriental Research 19 (1925), pp. 5-19. \\ 1934 The Kyle Memorial Excavation at Bethel: Bulletin of the American School of Oriental \\ Research 56 (1934), pp. 2-15. \\ BE'ERI, R. - COHEN, O. \\ 2012 The Iron Age Pottery: A. Zertal (ed.), El-Ahwat, A Fortified Site from the Early Iron \\ Age near Nahal 'Iron, Israel. Excavations 1993-2000 (Culture and History of the Ancient \\ BERLIN, A.M. \\ Near East 24), Leiden - Boston 2012, pp. 181-224. \\ 2015 Hellenistic Period: S. Gitin (ed.), The Ancient Pottery of Israel and its Neighbors. From \\ the Iron Age trough the Hellenistic Period (Israel Exploration Society), Jerusalem 2015, \\ pp. 629-671. \\ BuHL, M.-L. - HOLM-NiELSEN, S. \\ 1969 Shiloh, the Danish Excavations at Tall Sailūn, Palestine, in 1926, 1929, 1932, and 1963 \\ The Pre-Hellenistic Remains (Publication of the National Museum, Archaeological- \\ Historical Series I vol. XII), Copenhagen 1969. \\ BunimovitZ, S. - FinKELSTEIN, I. \\ 1993 Pottery: I. FinKelstein - S. Bunimovitz - Z. LEDERMAn, Shiloh, the Archaeology of a \\ Biblical Site (Monograph Series of the Institute of Archaeology 10), Tel Aviv 1993. \\ CAMPBELL, E.F. JR. \\ 1991 Shechem II. Portrait of a Hill Country Vale: The Shechem Regional Survey (American \\ School of Oriental Research Archaeological Reports 2), Atlanta 1991. \\ CHAMBOn, A. \\ 1984 Tell el-Far'ah 1. L’Age du Fer (Éditions Recherche sur les Civilisations, "Mémoire” n. \\ 31), Paris 1984. \\ COLE, D. \\ 1965 Middle Bronze IIB Pottery at Shechem (microfilmed PhD Thesis at Drew University), \\ Madison - New Jersey 1965 \\ CONDER, C.R. - KITCHENER, R.E. \\ 1882 The Survey of the Western Palestine (Memoirs of the Topography, Orography, \\ Hydrography and Archaeology, Vol. II, Sheets VII.-XVI. Samaria), London 1882. \\ Crowfoot, J.W. - CROWFOOT, G.M. - KENYON, K.M. \\ $1957 \quad$ Samaria-Sebaste III: The Objects from Samaria, London 1957. \\ ESSE, D. \\ 1991 The Collared Store Jar: Scholarly Ideology and Ceramic Typology: Scandinavian Journal \\ of the Old Testament 5 (1991), pp. 99-116.
}


FINKELSTEIN, I.

1986 Pottery and Stone Artifacts: I. FinKelstein, 'Izbet Șartah, An Early Iron Age Site near Rosh Ha ayin, Israel (British Archaeological Reports International Series 299), Oxford 1986, pp. 38-95.

1988a The Archaeology of the Israelite Settlement, Jerusalem 1988.

1988b The Land of Ephraim Survey 1980-1987: Preliminary Report: Tel Aviv 15-16 (1988), pp. 117-183.

1990 Excavations at Khirbet ed-Dawwara, an Iron Age Site Northeast of Jerusalem: Tel Aviv 17 (1990), pp. 163-208.

FinKelstein, I. - BunimovitZ, S. - LeDERMAn, Z.

1997 Highlands of many cultures: the Southern Samaria Survey: The Sites (Monograph Series of the Institute of Archaeology 14), Tel Aviv 1997.

FINKELSTEIN, I. - GOPHNA, R.

1993 Settlement, Demographic and Economic Patterns in the Highlands of Palestine in the Chalcolithic and Early Bronze Age Periods and the Beginning of Urbanism: Bulletin of the American School of Oriental Research 289 (1993), pp. 1-22.

GABRIELI, R.S.- BEN-SHLOMO, D. - WALKER, B.J.

2014 Production and Distribution of Hand-Made Geometric-Painted (HMGP) and Plain HandMade Wares of the Mamluk Period: A Case Study from Northern Israel, Jerusalem and Tall Hisban: Journal of Islamic Archaeology 1/2 (2014), pp. 143-192.

GADOT, Y.

2009 Late Bronze and Iron Age Pottery: Y. Gadot - E. Yadin, Aphek-Antipatris II. The Remains on the Acropolis. The Moshe Kochavi and Pirhiya Beck Excavations GUERIN, M.V. (Monograph Series of the Institute of Archaeology 27), Tel Aviv 2009.

1875 Description Géographique, Historique et Archéologique de la Palestine, Samarie, Tome II, Paris 1875.

JENNI, E.

1958 Historisch-topographische Untersuchungen zur Grenze zwischen Ephraim und Manasse: Zeitschrift des Deutschen Palästina-Vereins 74 (1958), pp. 35-40.

KALLAI, Z.

$1986 \quad$ Historical Geography of the Bible. The Tribal Territories of Israel, Jerusalem 1986.

KELSO, J.L.

1968 The Excavation of Bethel (1934-1960) (Annual of the American Schools of Oriental Research XXXIX), Cambridge 1968.

KENYON, K.M. - HOLLAND, T.A.

$1982 \quad$ Excavations at Jericho IV. The Pottery Type Series and Other Finds, Oxford 1982.

MASTER, D.M.

2005a The Iron Age: Area A: D.M. MASTER - J.M. Monson - E.H.E. LASS - G.A. PierCe (eds.), Dothan I: Remains from the Tell (1953-1964), Winona Lake 2005, pp. 67-86.

2005b The Iron Age: Area L and Area K: D.M. MASTER - J.M. MONSON - E.H.E. LASS - G.A. PIERCE (eds.), Dothan I: Remains from the Tell (1953-1964), Winona Lake 2005, pp. 87129.

2005c The Islamic Period: D.M. MASTER - J.M. MONSON - E.H.E. LAsS - G.A. Pierce (eds.), Dothan I: Remains from the Tell (1953-1964), Winona Lake 2005, pp. 147-160.

MAZAR, A.

1981 Giloh. An Early Israelite Settlement Site near Jerusalem: Israel Exploration Journal 31 (1981), pp. 1-36. 
1990 Iron Age I and II Towers at Giloh and the Israelite Settlement: Israel Exploration Journal 40 2/3 (1990), pp. 76-101.

2015 Iron Age I: Northern Coastal Plain, Galilee, Samaria, Jezreel Valley, Judah, and Negev: S. Gitin (ed.), The Ancient Pottery of Israel and its Neighbors. From the Iron Age trough the Hellenistic Period (Israel Exploration Society), Jerusalem 2015, pp. 5-70.

NoTH, $\mathrm{M}$.

1966 Das Deutsche Evangelische Institut für Altertumswissenschaft des Heiligen Landes im Jahre 1965: Zeitschrift des Deutschen Palästina-Vereins 82 (1966), pp. 255-273.

PRINGLE, D.

1994 Towers in Crusader Palestine: Chateau Gaillard XVI (1994) (Actes du Colloque International tenu à Luxembourg 23-29 Aout 1992), pp. 335-350.

PRITCHARD, J.B.

1963 The Bronze Age Cemetery at Gibeon (Museum Monographs), Philadelphia 1963.

ROSENTHAL-HEGINBOTTOM, R.

2015 Hellenistic Period Imported Pottery: S. GiTiN (ed.), The Ancient Pottery of Israel and its Neighbors. From the Iron Age trough the Hellenistic Period (Israel Exploration Society), Jerusalem 2015, pp. 673-708.

SAULCY DE, F.

$1865 \quad$ Voyage en Terre Sainte, Tome 2, Paris 1865.

SAYEJ, G.J.

1999 The origins of terraces in the central hills of Palestine: theories and explanations: I. ABULughOD - R. HEACOCK - K. NASHEF (eds.), The Landscape of Palestine: Equivocal Poetry (Birzeit University Publications), Ramallah 1999, pp. 201-209.

STERN, E.

2015 Persian Period: S. GiTin (ed.), The Ancient Pottery of Israel and its Neighbors. From the Iron Age trough the Hellenistic Period (Israel Exploration Society), Jerusalem 2015, pp. 565-617.

TAPPY, R.E.

2015a Iron Age IIA-B: Samaria: S. Gitin (ed.), The Ancient Pottery of Israel and its Neighbors. From the Iron Age trough the Hellenistic Period (Israel Exploration Society), Jerusalem 2015, pp. 189-211.

2015b Iron Age IIC: Samaria: S. GiTIN (ed.), The Ancient Pottery of Israel and its Neighbors. From the Iron Age trough the Hellenistic Period (Israel Exploration Society), Jerusalem 2015, pp. 327-344.

ZERTAL, A.

1986-1987 An Early Iron Age Cultic Site on Mount Ebal: Excavation Seasons 1982-1987: Tel Aviv 13-14 (1986-1987), pp. 105-165.

2007 The Manasseh Hill Country Survey. Vol. 2: The Eastern Valleys and the Fringes of the Desert (Culture and History of the Ancient Near East), Leiden - Boston 2007. 

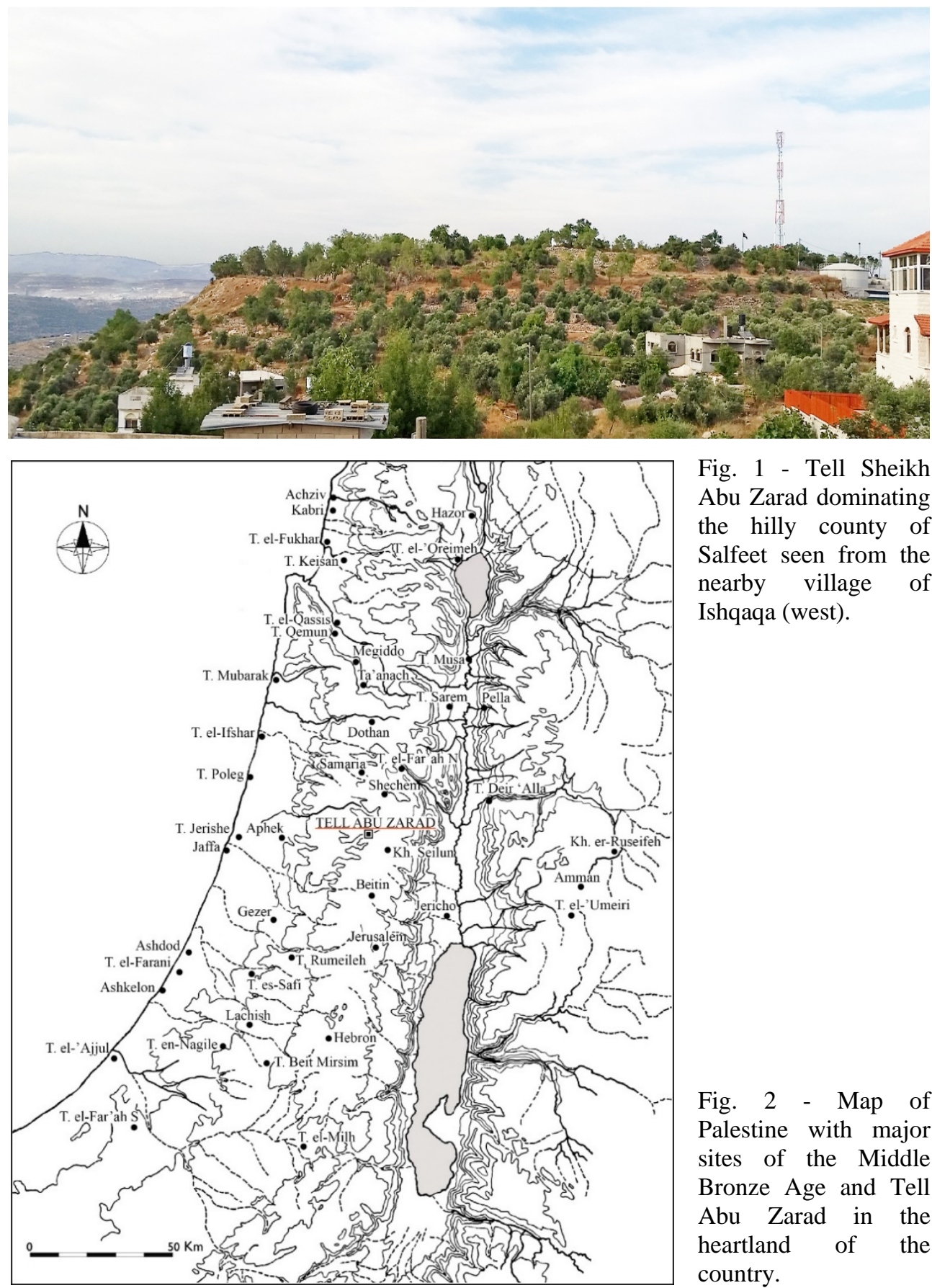

Fig. 1 - Tell Sheikh Abu Zarad dominating the hilly county of Salfeet seen from the nearby village of Ishqaqa (west).

Fig. 2 - Map of Palestine with major sites of the Middle Bronze Age and Tell Abu Zarad in the heartland of the country. 

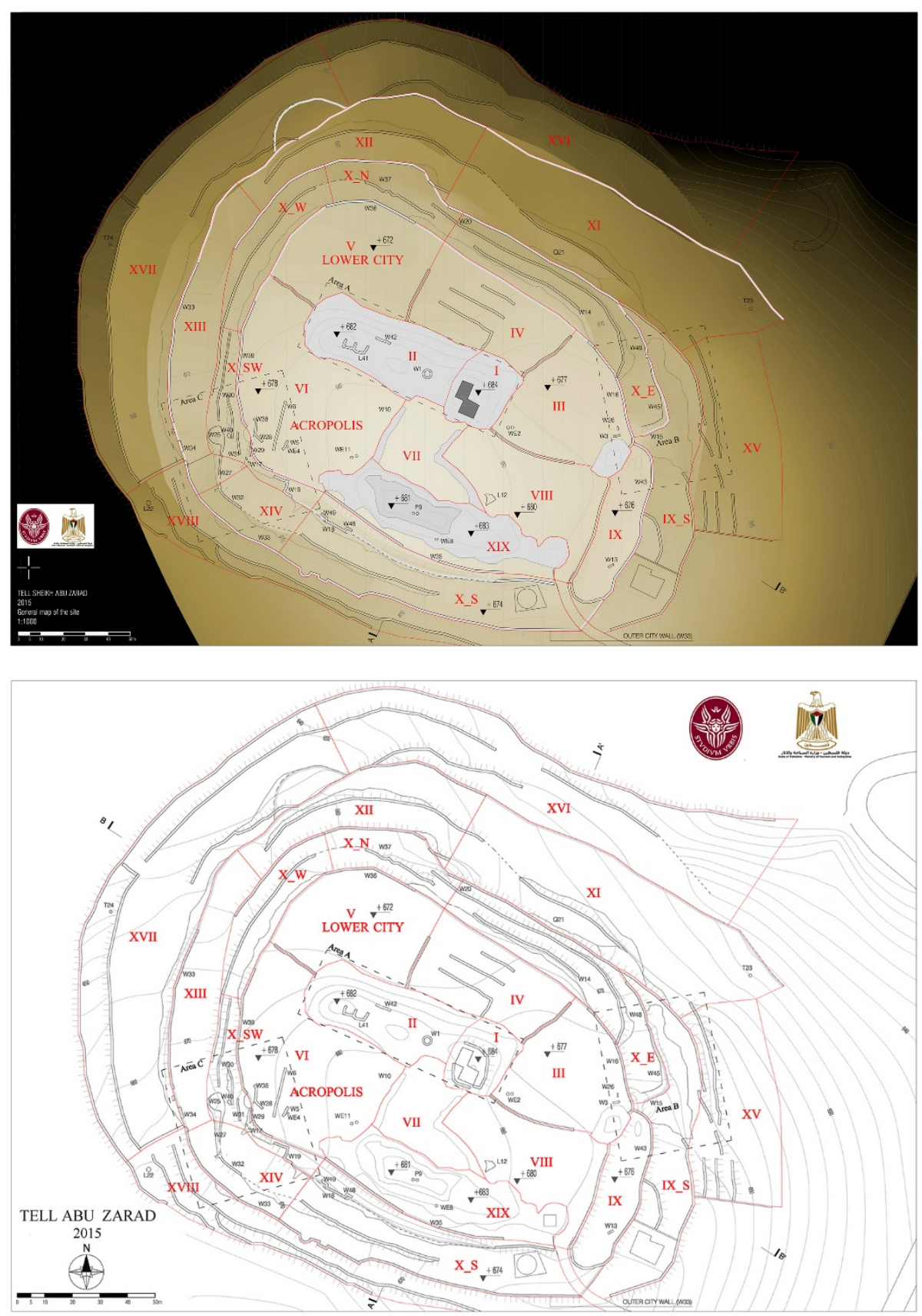

Fig. 3 - Maps of Tell Abu Zarad with major archaeological features, areas and sectors. 


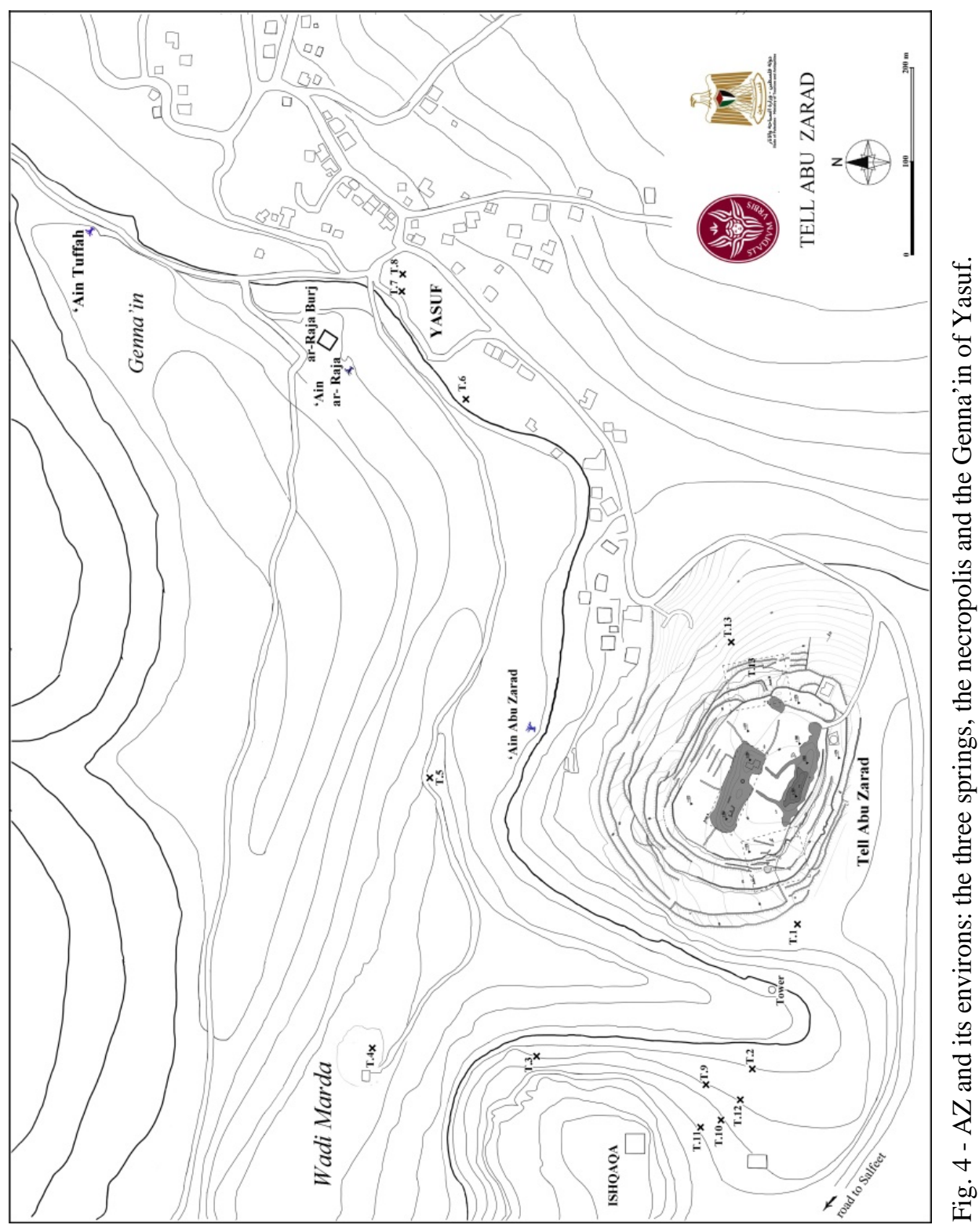




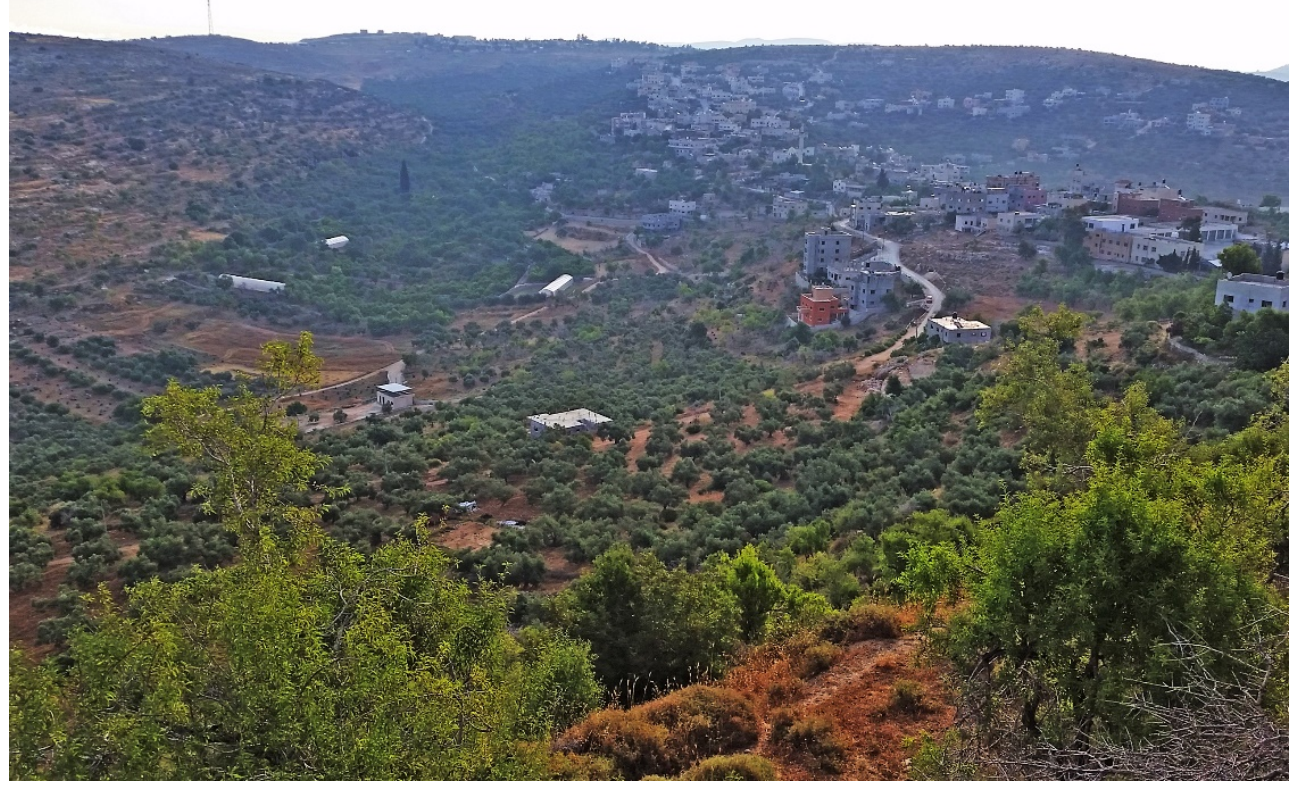

Fig. 5 - The Genna'in of Yasuf with the olive trees grove seen from the tell.

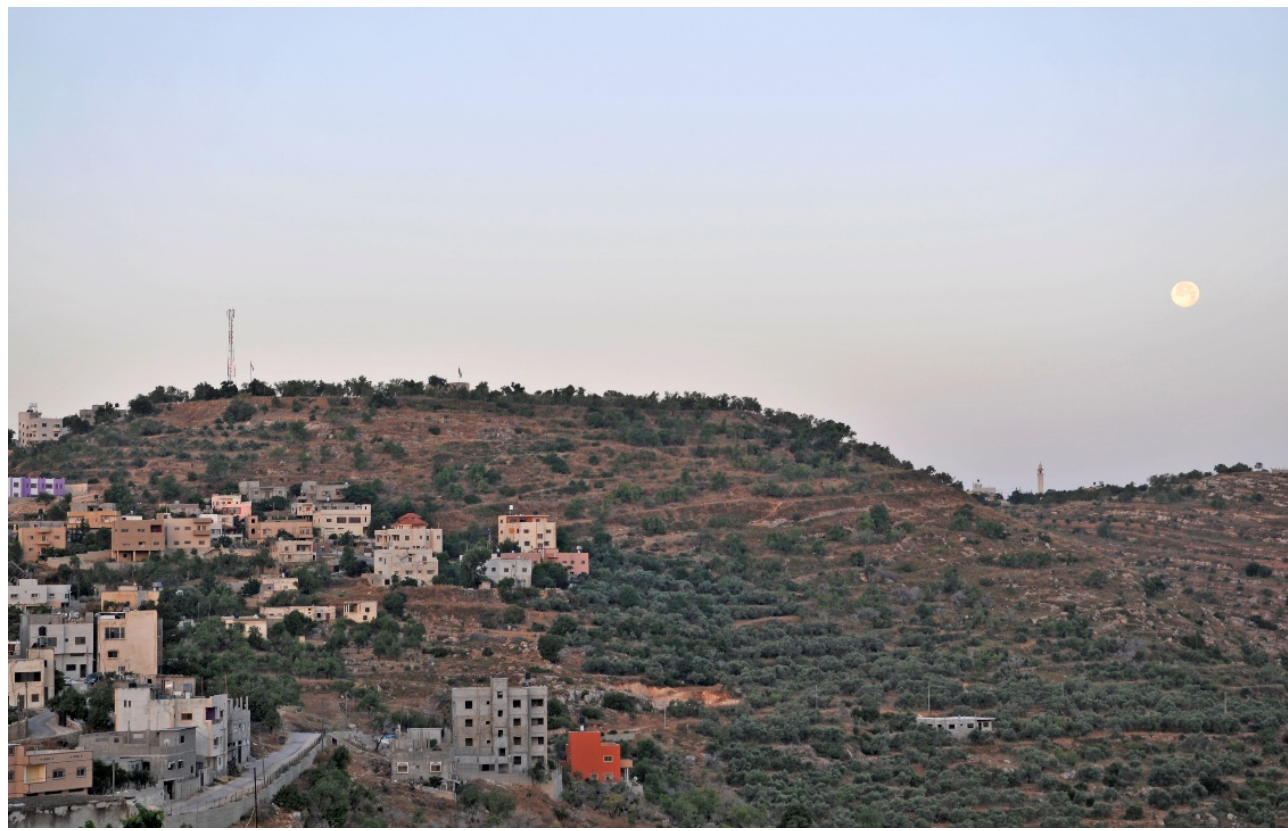

Fig. 6 - Tell Abu Zarad seen from the east (from the house of the expedition in Yasuf). 


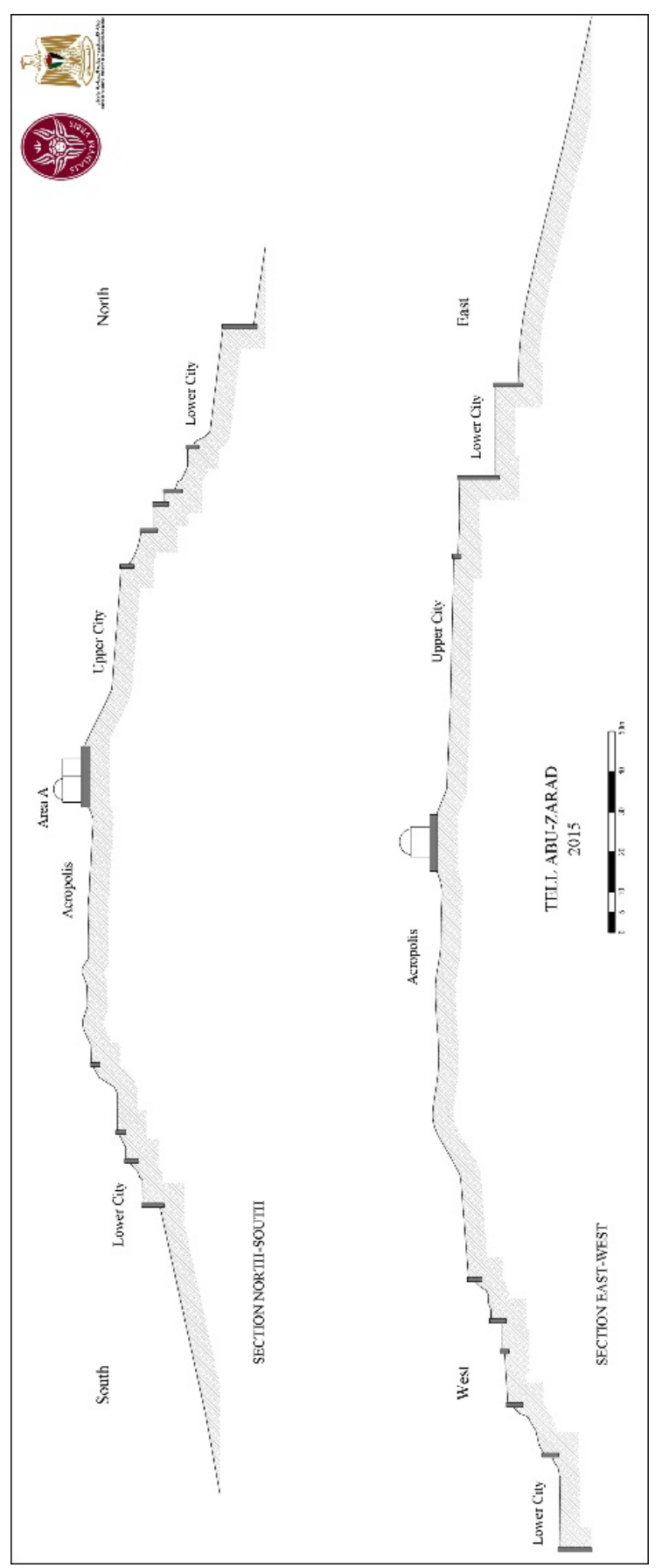




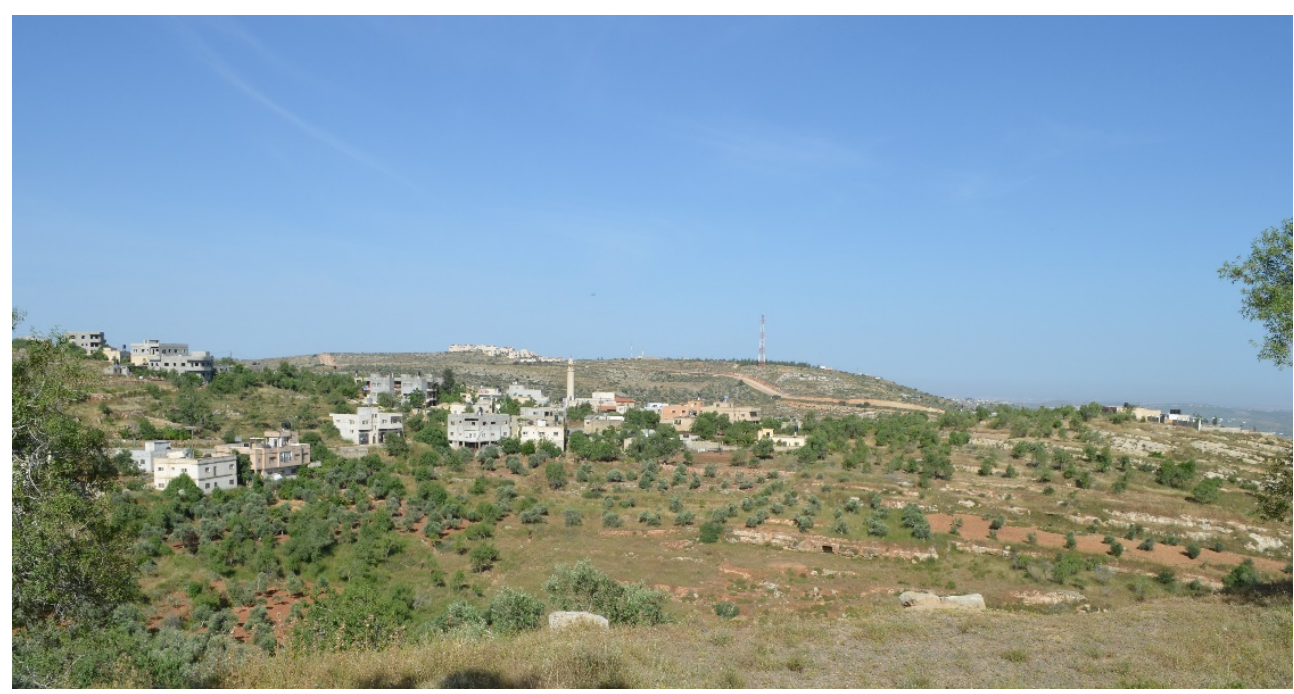

Fig. 8 - View from AZ towards the west with the nearby hamlet of Ishqaqa and the rocky terraces hosting the main necropolis of the site.

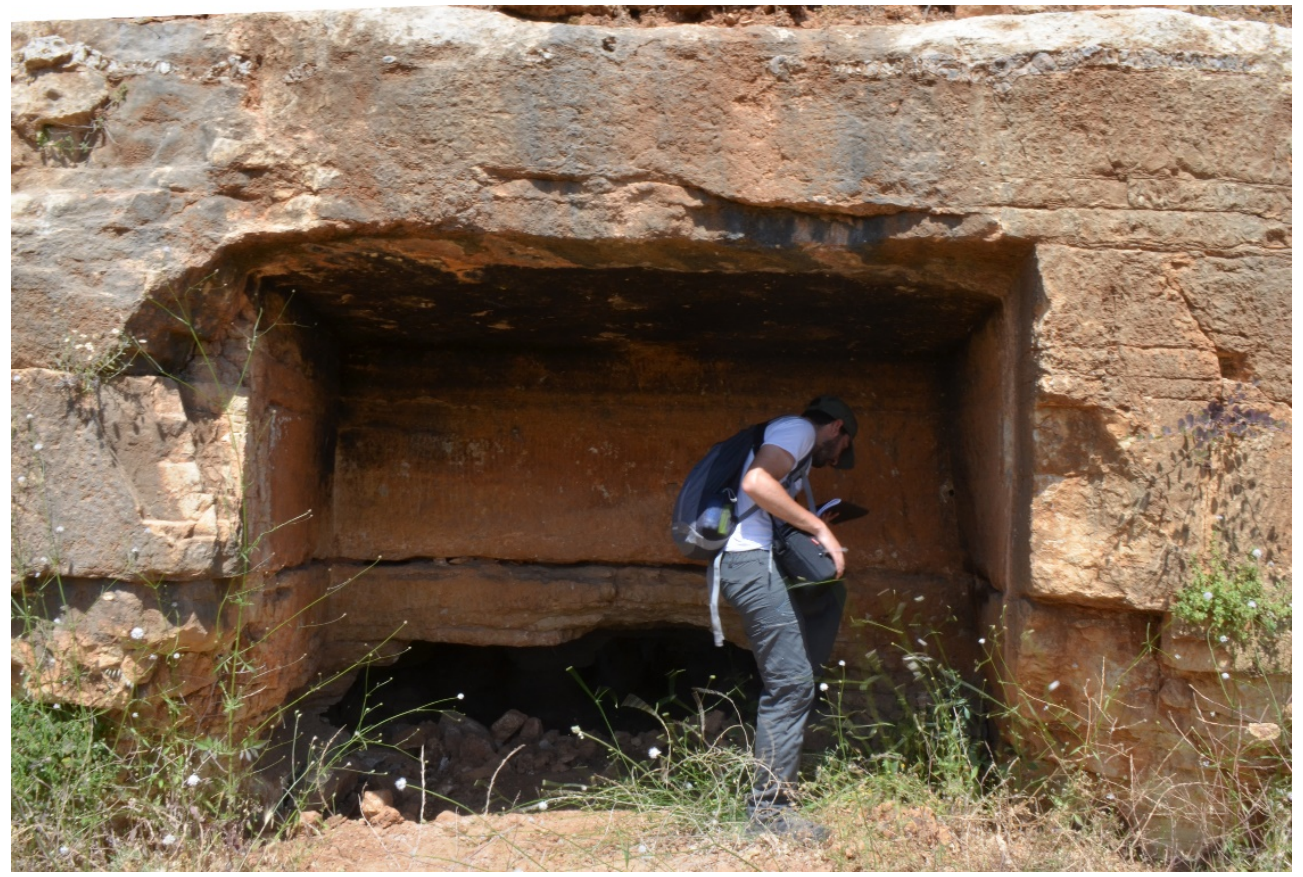

Fig. 9 - The rock-cut entrance of Tomb 2. 


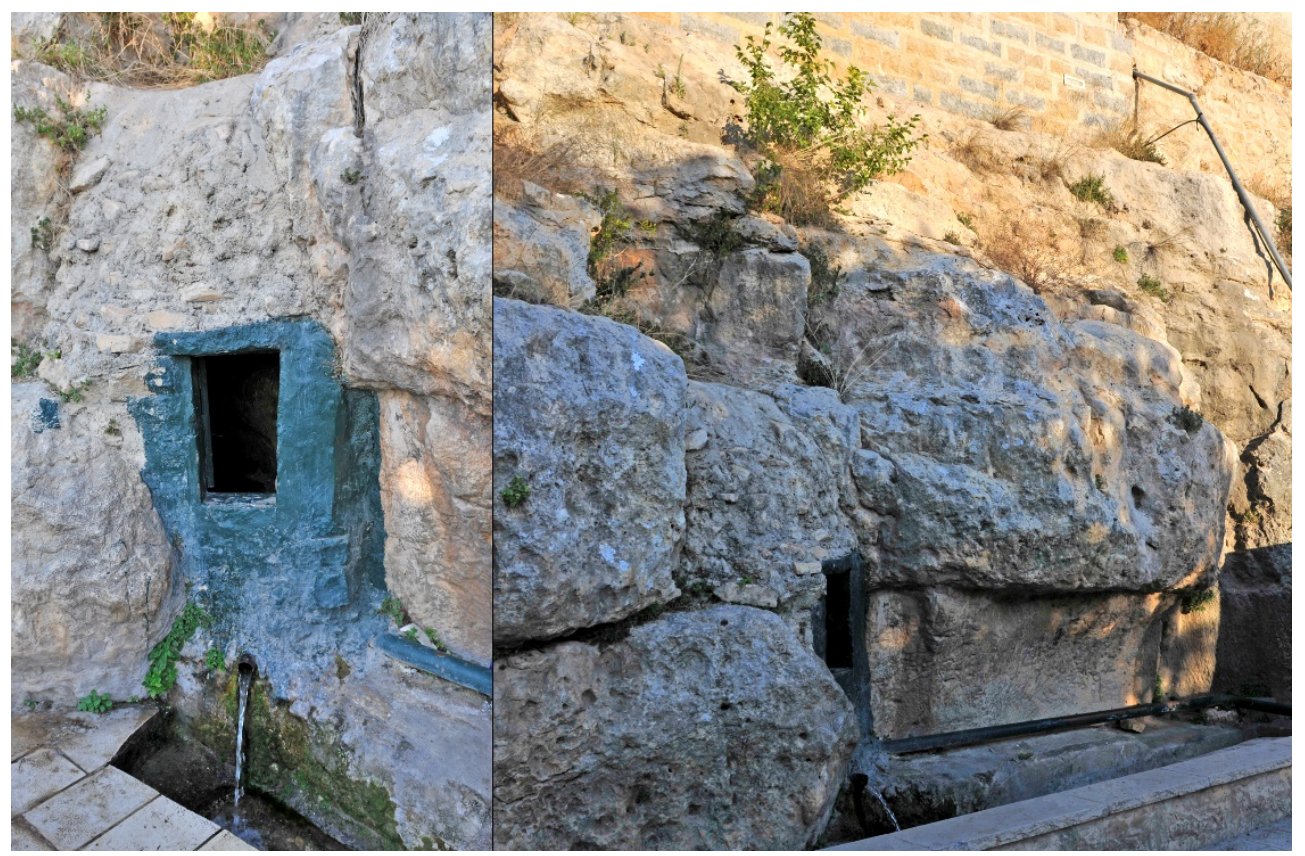

Fig. 10 - 'Ain Yasuf spilling out of the rock step concealing phreatic aquifer.
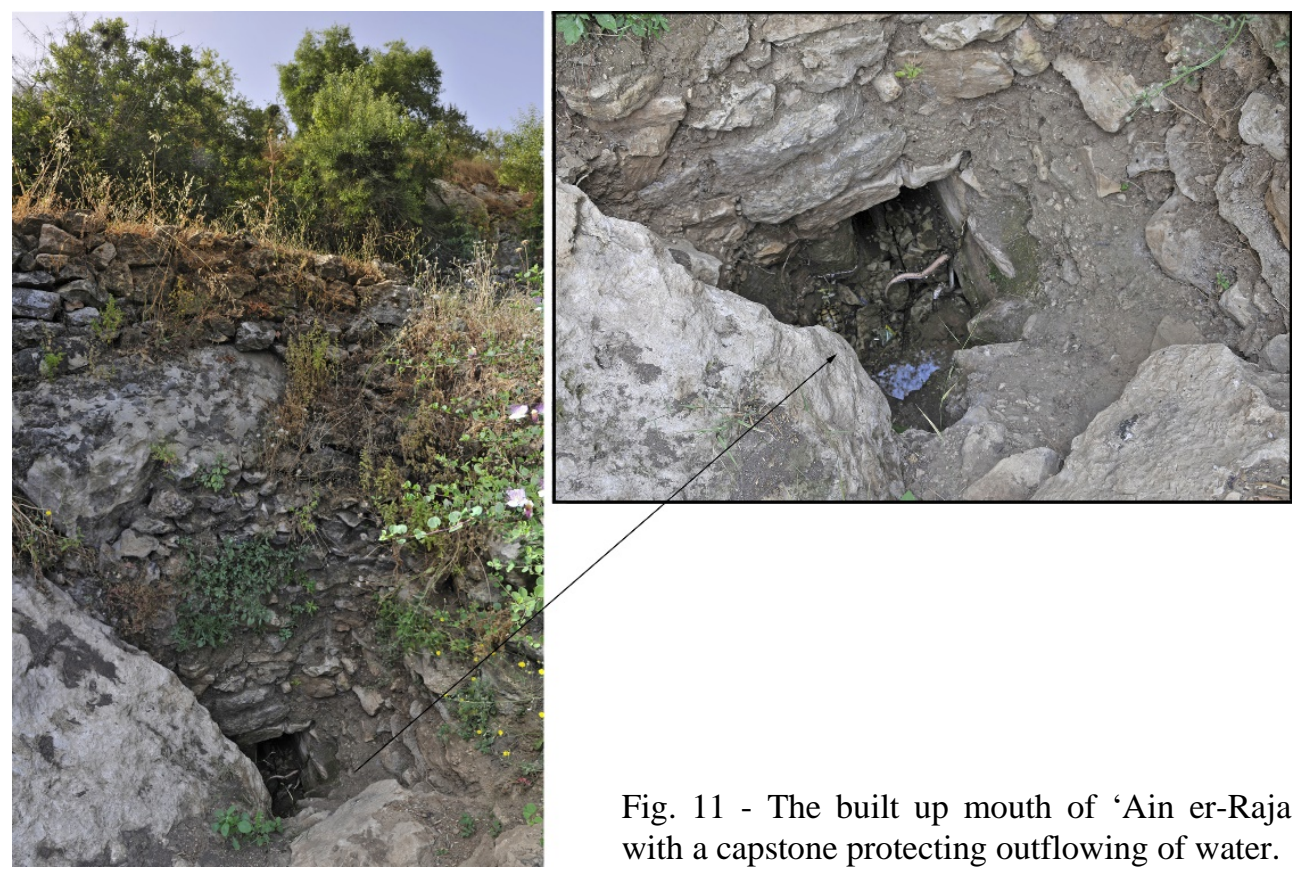

Fig. 11 - The built up mouth of 'Ain er-Raja with a capstone protecting outflowing of water. 


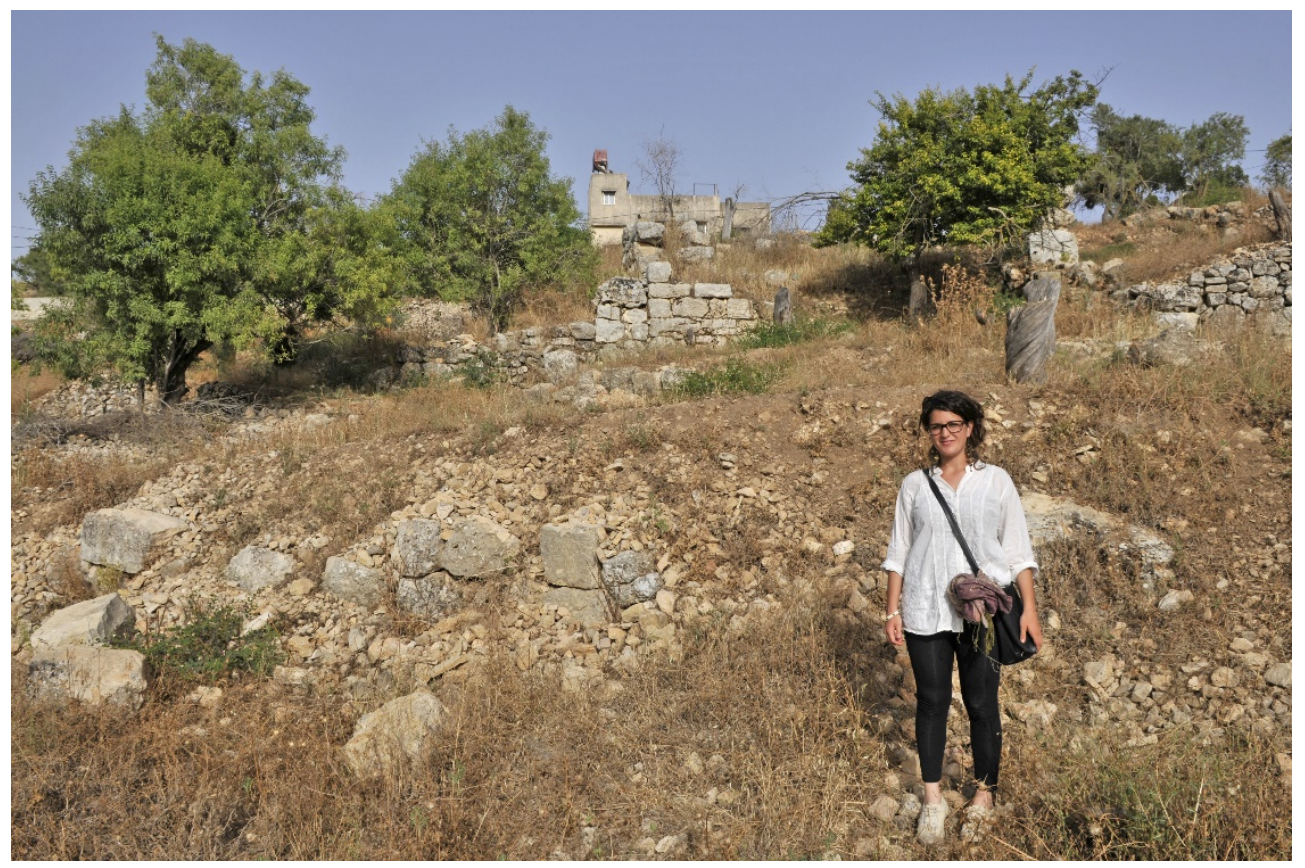

Fig. 12 - Er-Raja Burj dating back from the Hellenistic and Roman times.

Fig. 13 - The pit-hole entrance to a cave underlying the north corner of erRaja Burj, where hot-waters spill off.

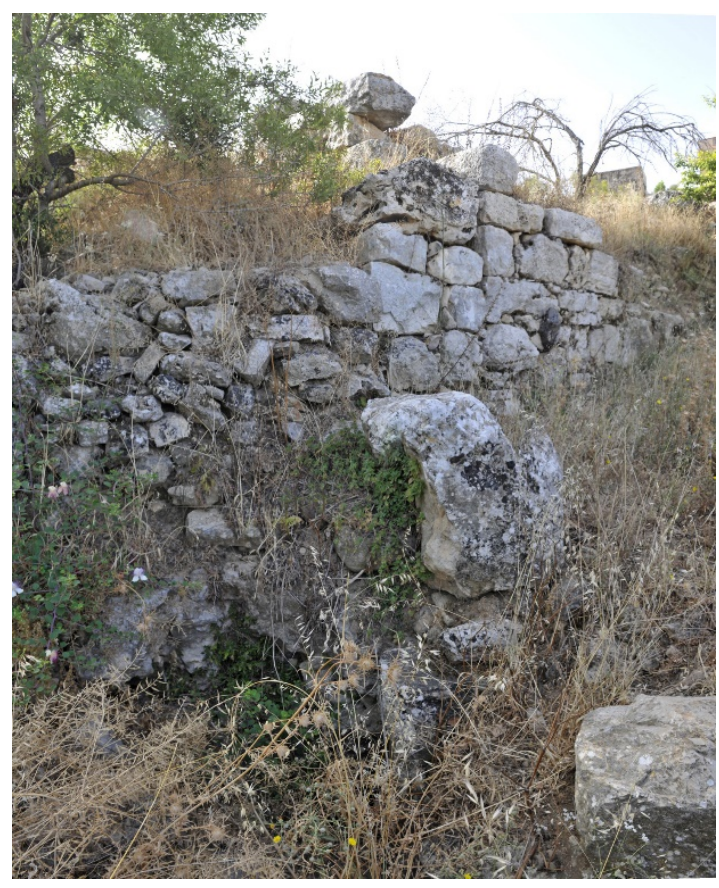




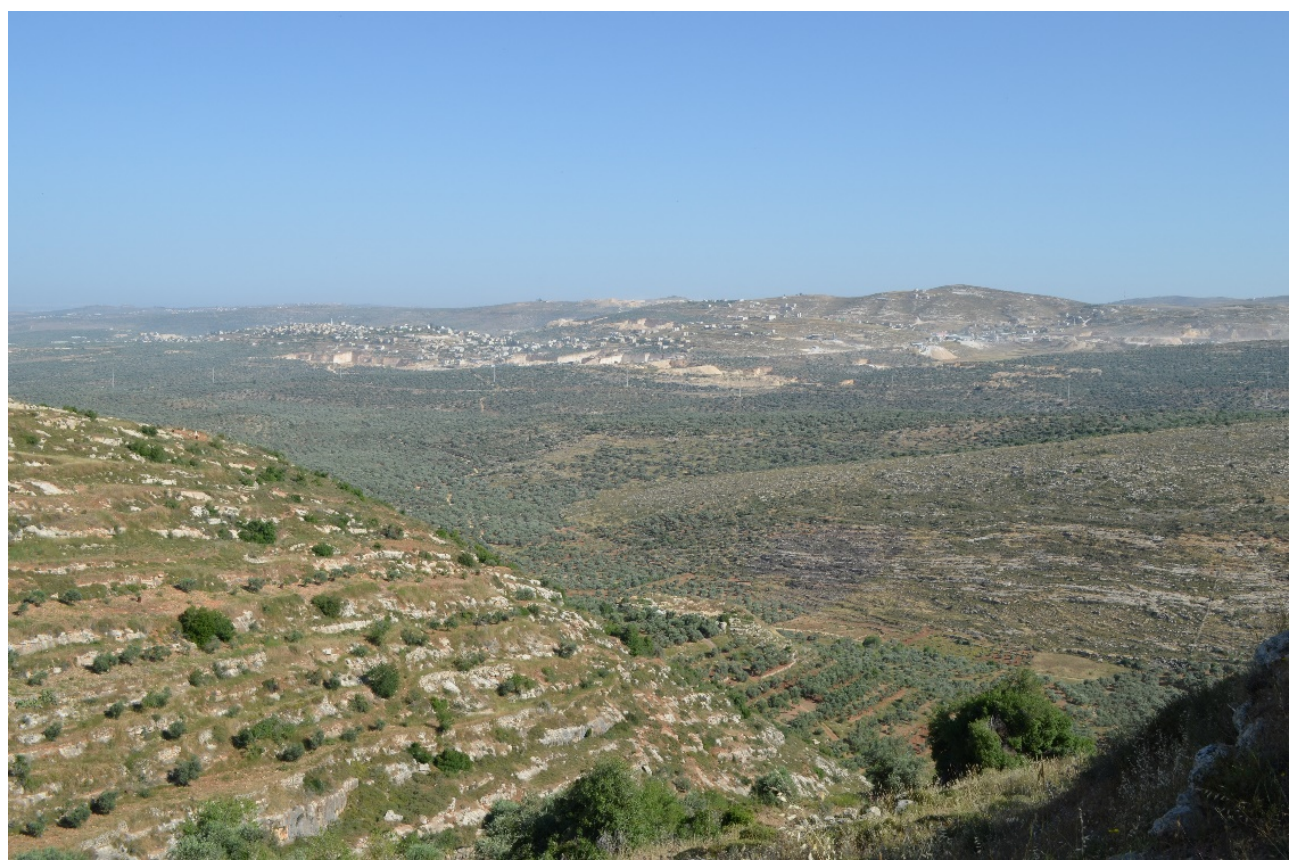

Fig. 14 - View of Wadi Marda and its fertile ecological niche from Tell Abu Zarad, looking north-west.

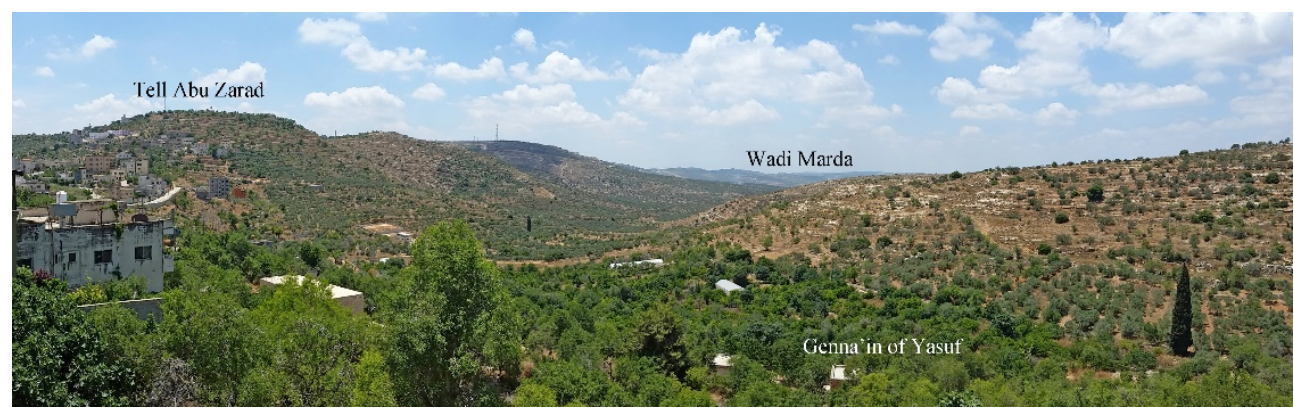

Fig. 15 - Panoramic view of the Genna'in of Yasuf; on the background Tell Abu Zarad and Wadi Marda. 


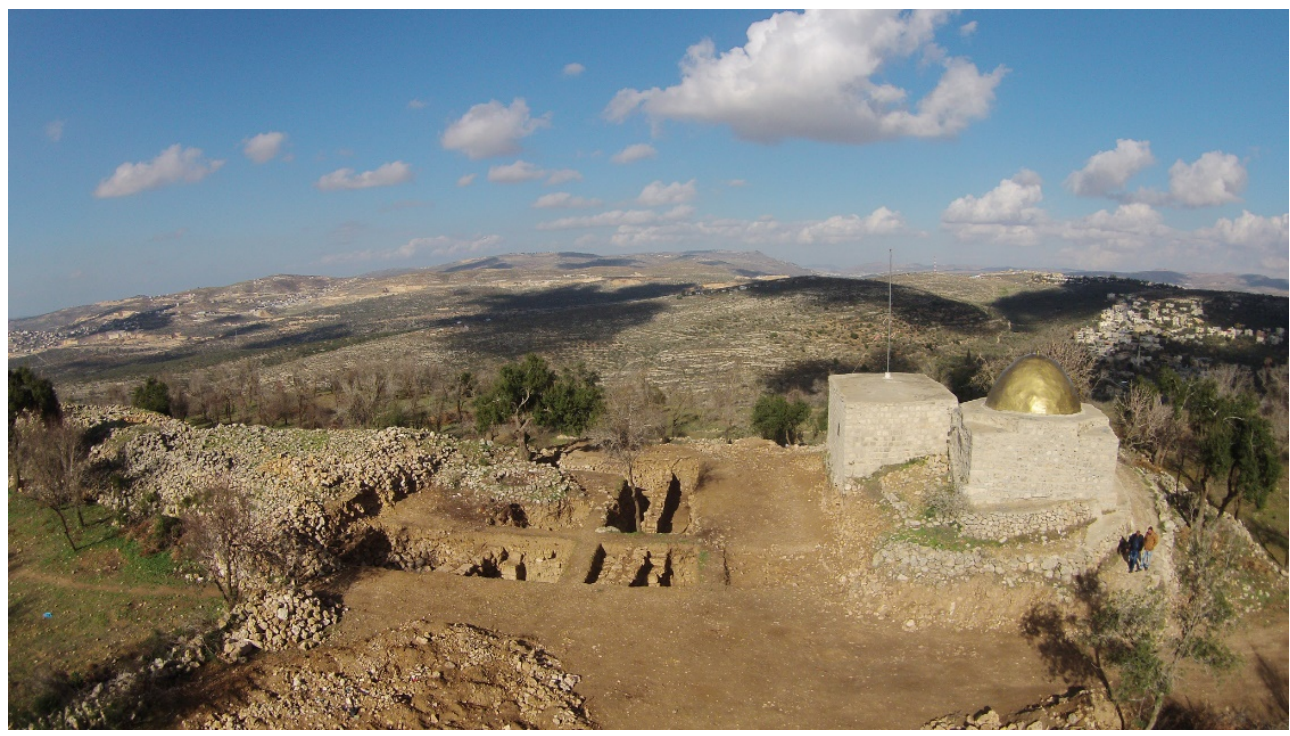

Fig. 16 - Tell Abu Zarad: aerial view of Area A, Sector I, with the maqam; in the middle, squares excavated in the second season (October-November 2015).

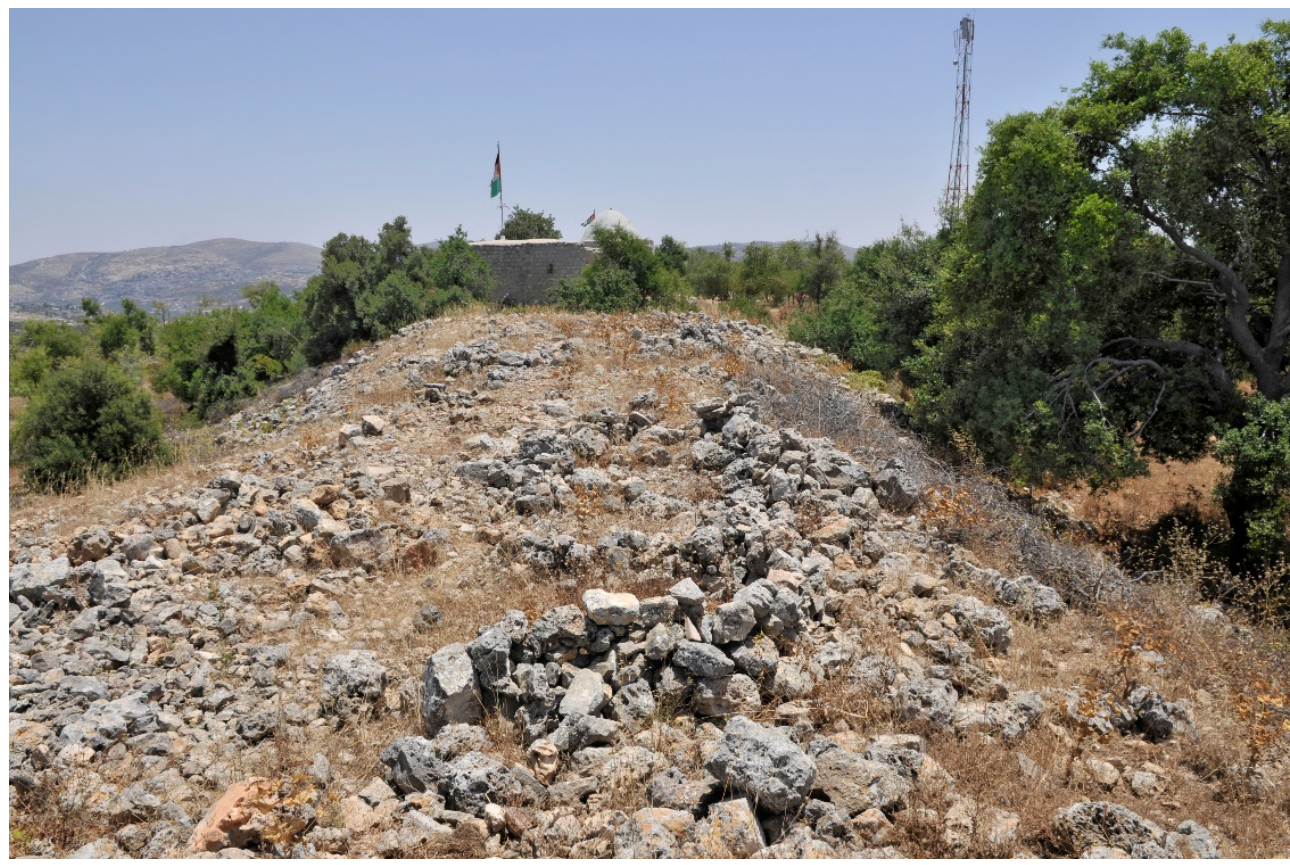

Fig. 17 - The remains of Building A1 in Area A, Sector II, on the acropolis summit. 


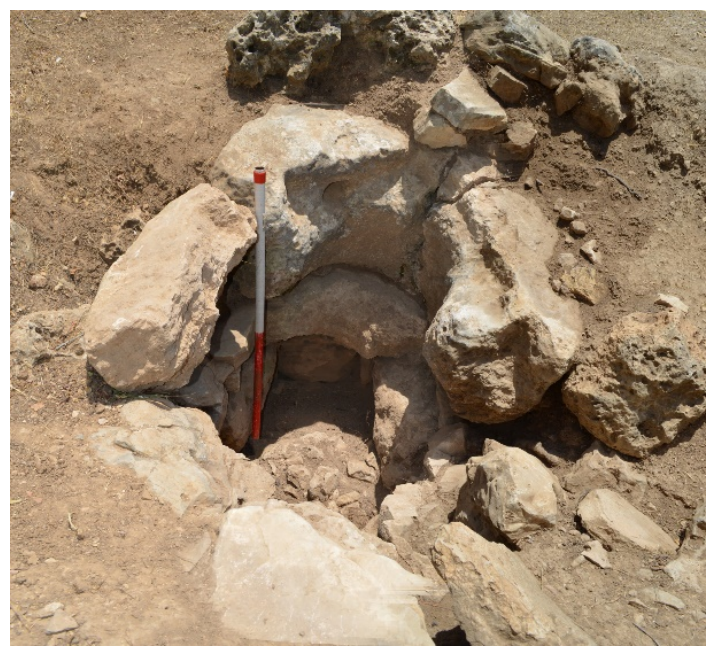

Fig. 18 - Well 2 in Sector III.

Fig. 19 - Well 4 and wall W.5 in Sector VI.

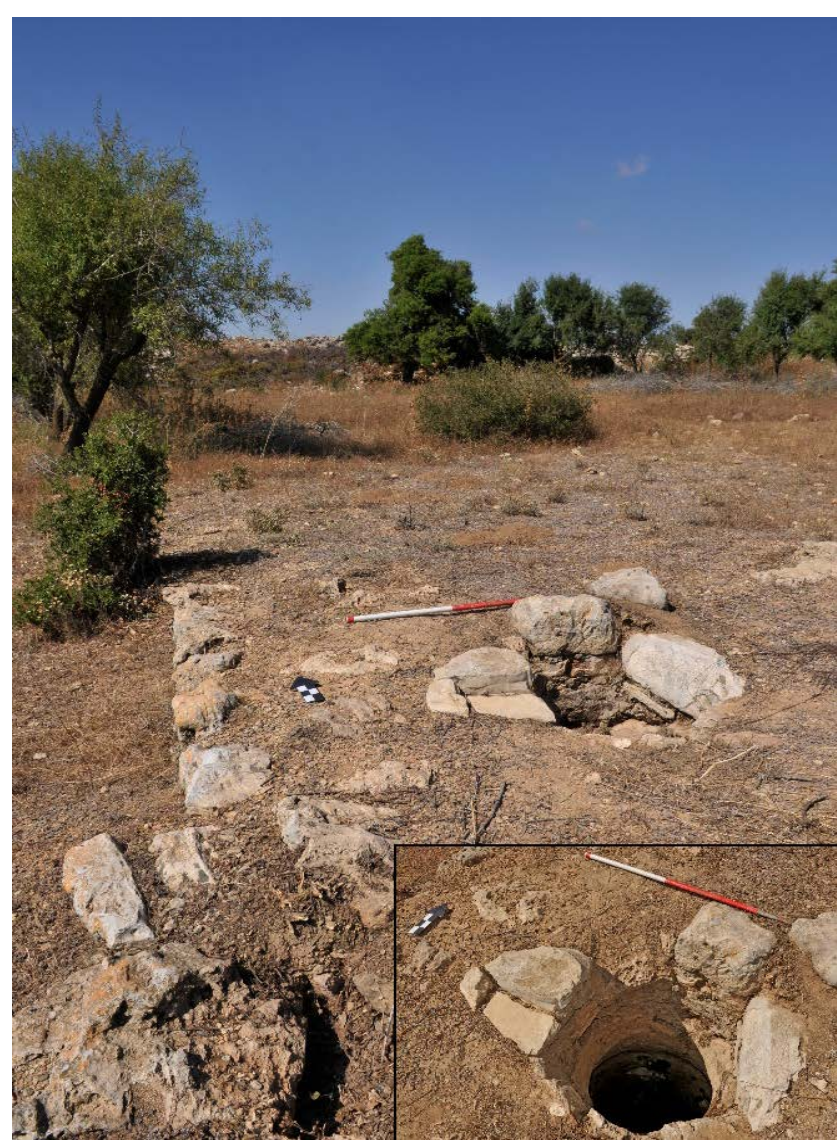




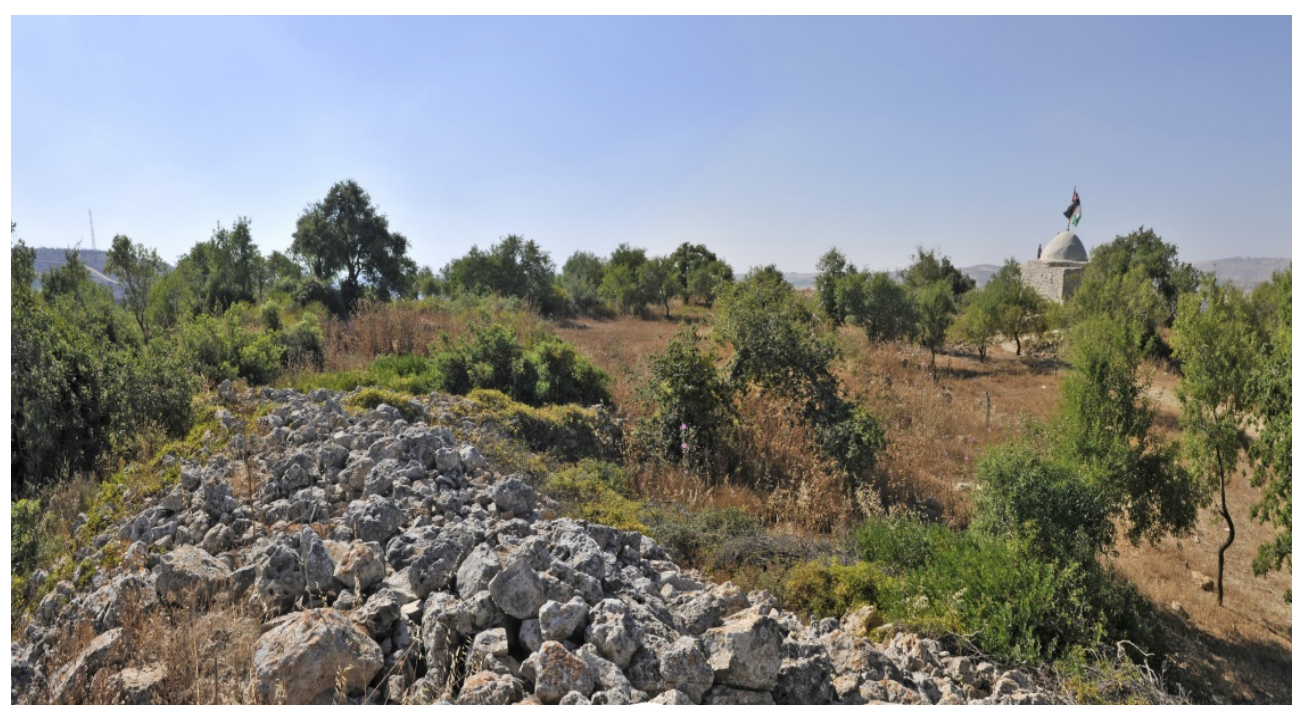

Fig. 20 - Collapsed stones of some major buildings in Sector XIX (the Acropolis southern summit).

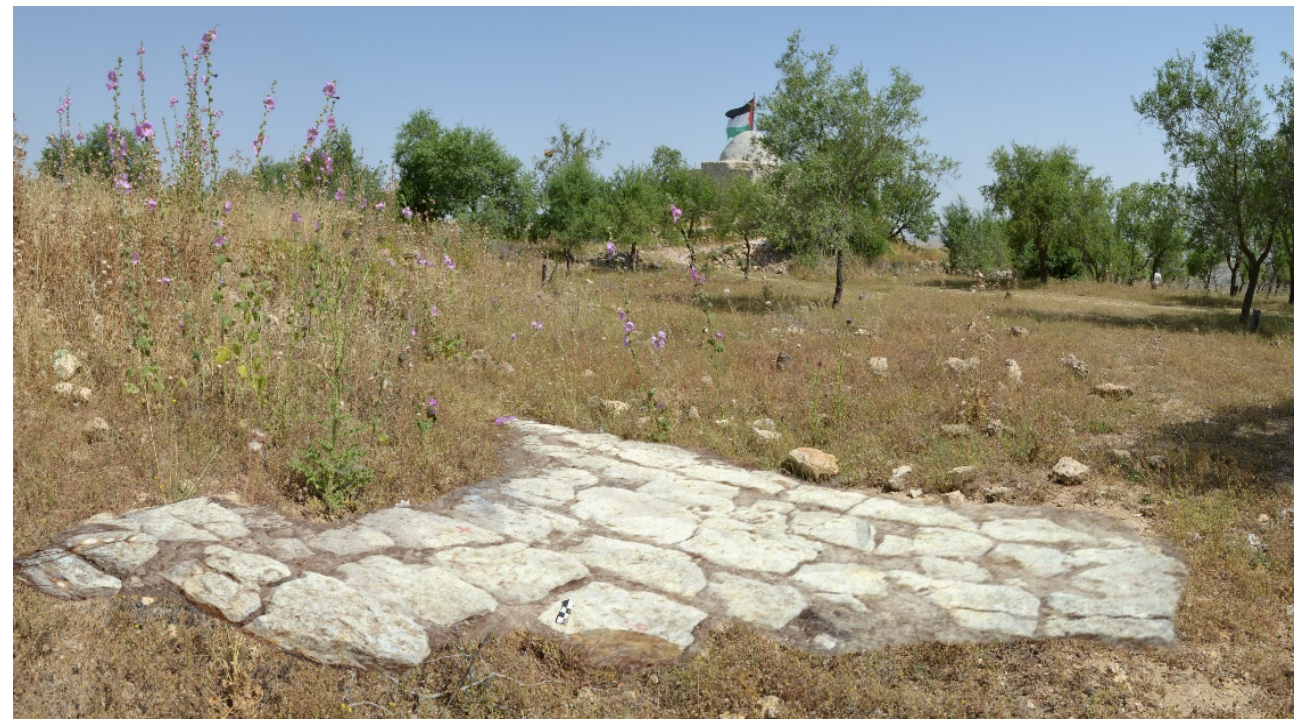

Fig. 21 - Slab paving L.12 uncovered in Sector VIII. 


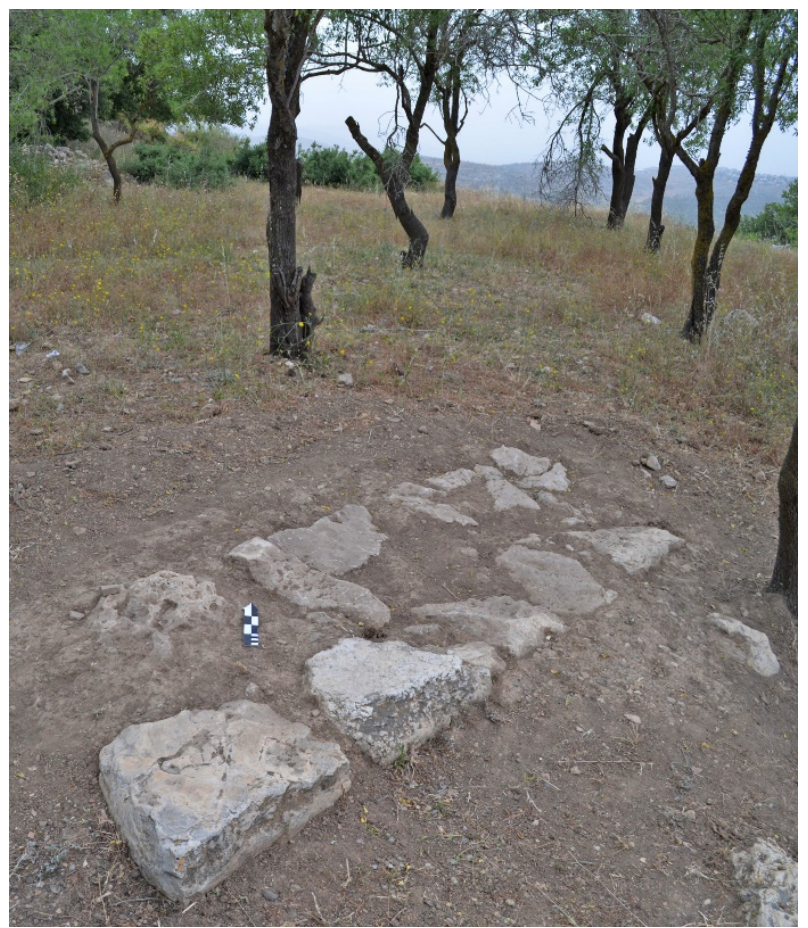

Fig. 22 - Wall W.13 in Sector IX.

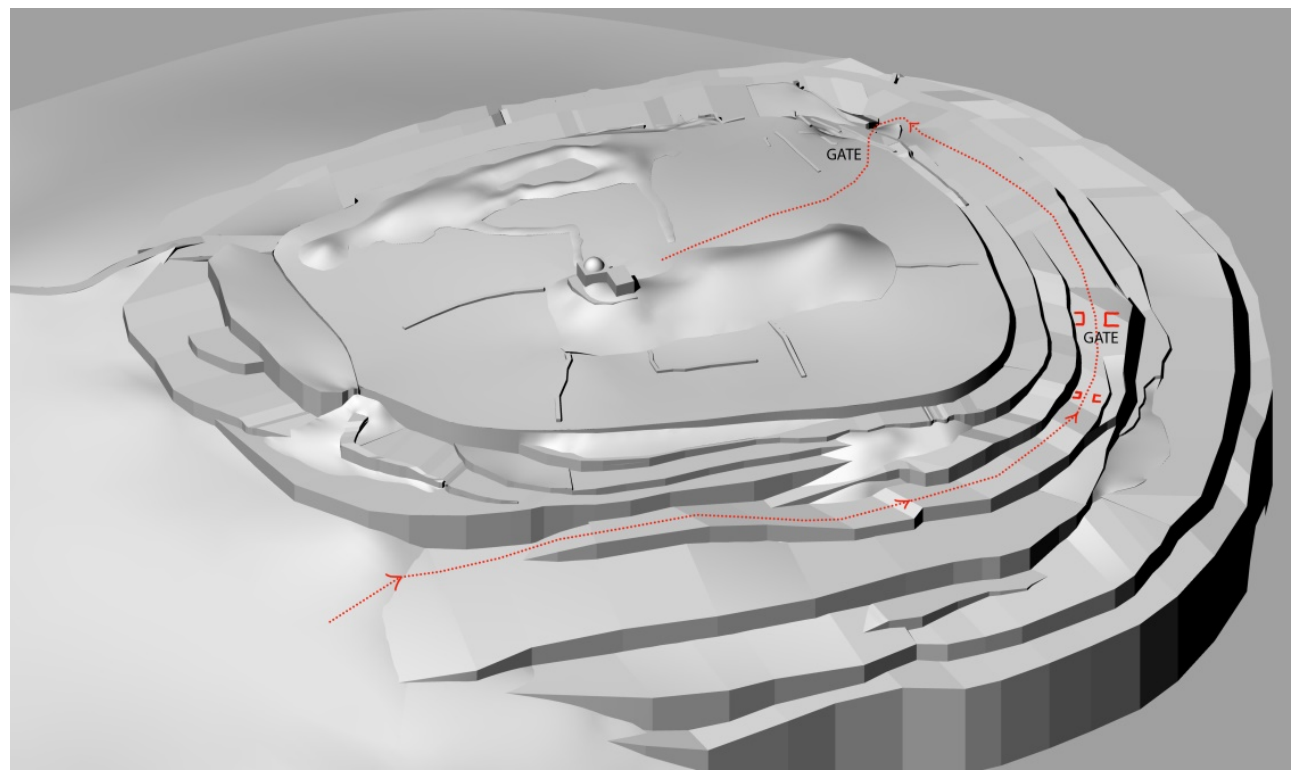

Fig. 23 - Model of Tell Abu Zarad with possible NW gate in Sector XII. 


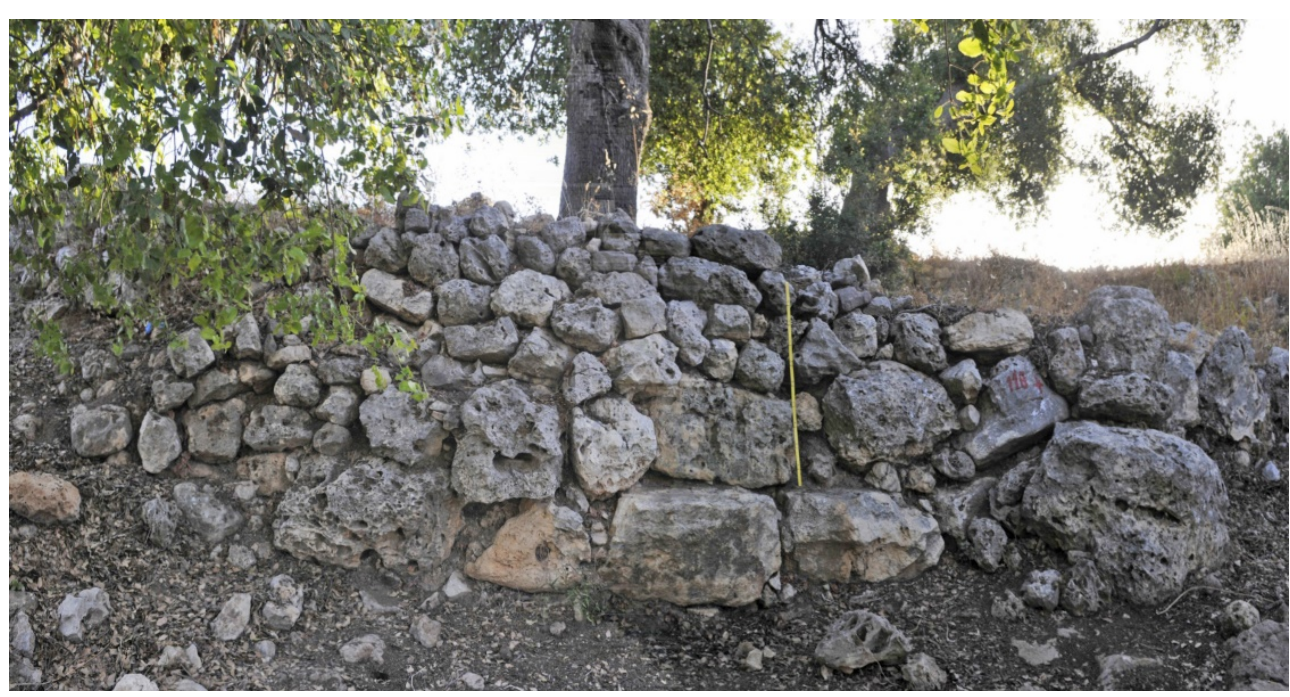

Fig. 24 - The fortification wall of the Acropolis W.19 made of big boulders in Sector XIV.

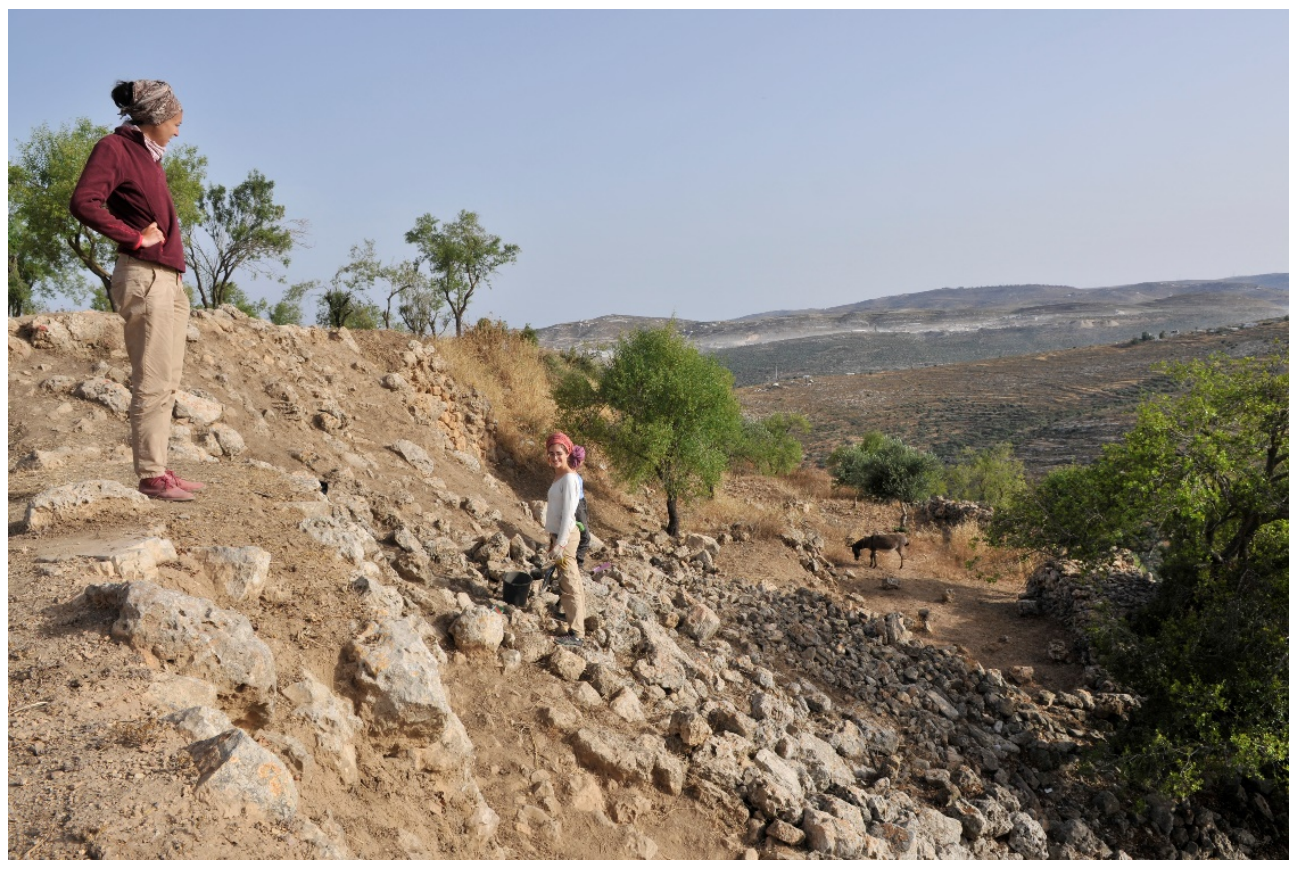

Fig. 25 - Upper City fortification wall W.16 with attached stepped wall W.15 in Area B, looking north. 


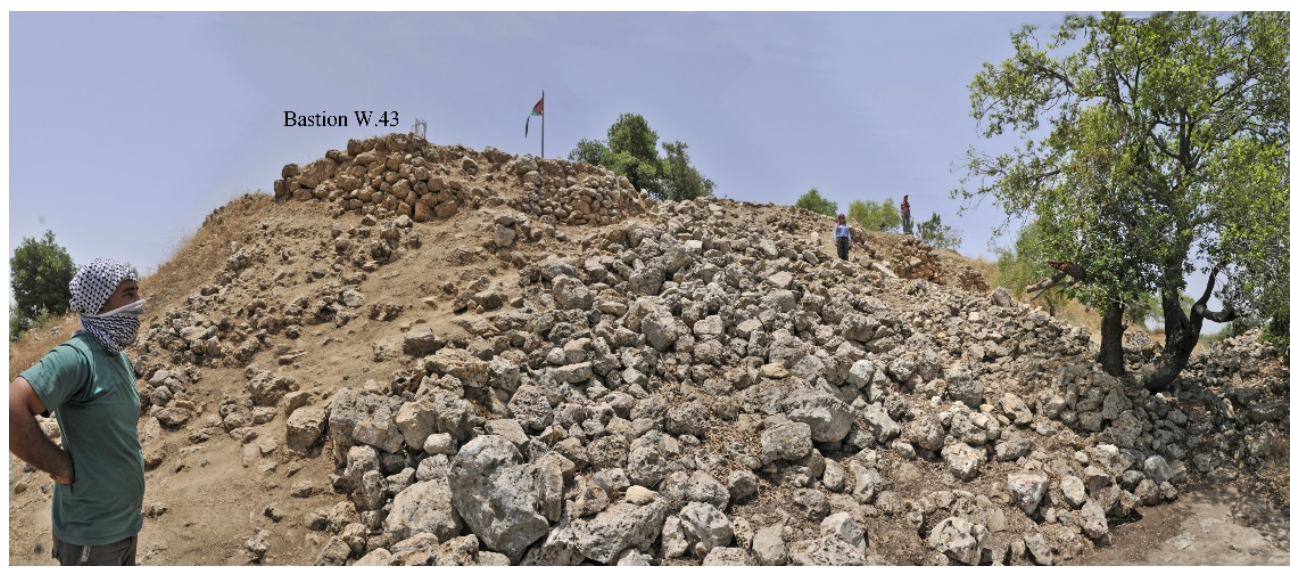

Fig. 26 - Bastion W.43 abutting from the line of the eastern fortifications of the Upper City seen from the foot of the stepped wall.

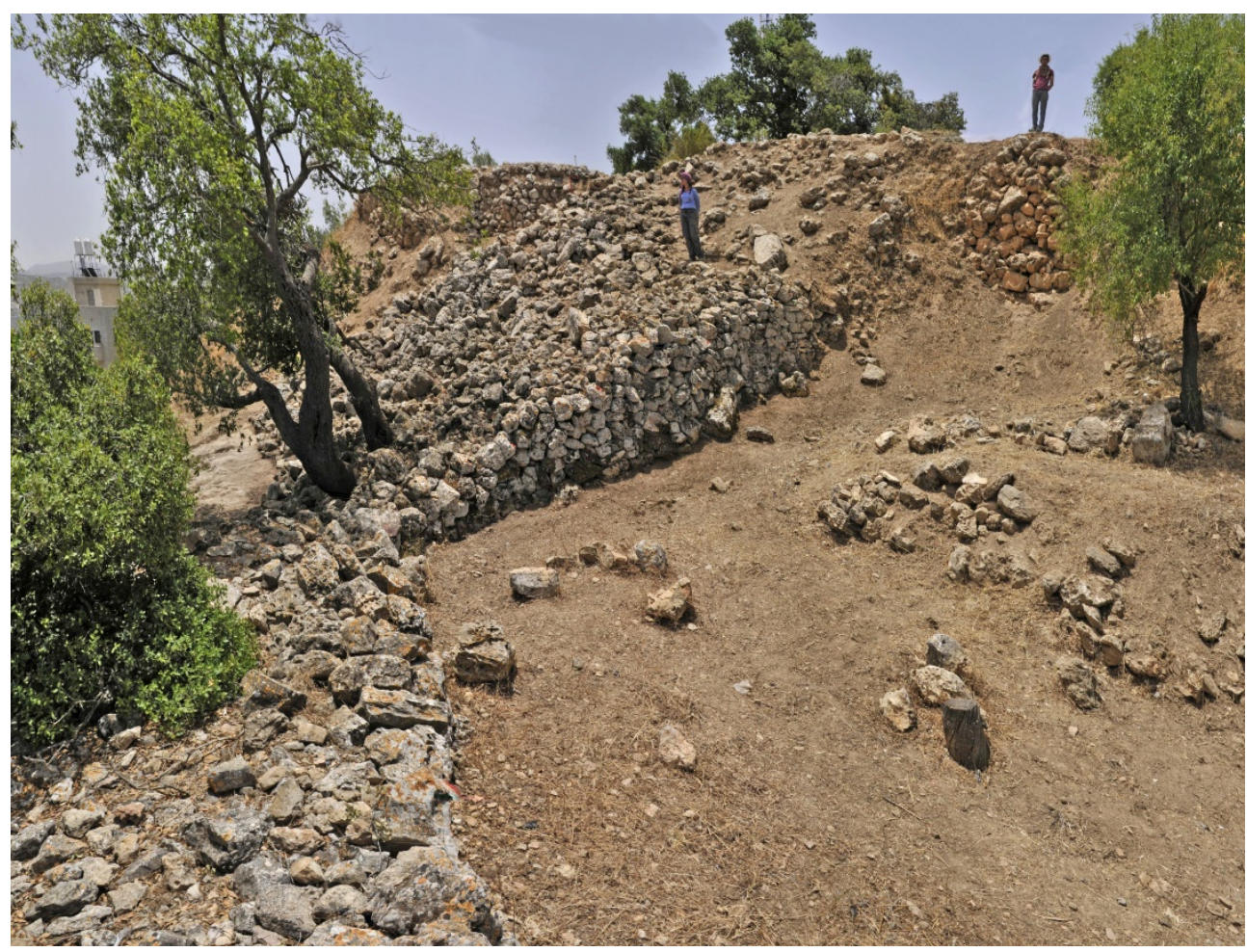

Fig. 27 - External structures (W.15+W.45) forming an advanced defence line in Area B, running on the edge of a main bedrock step. 


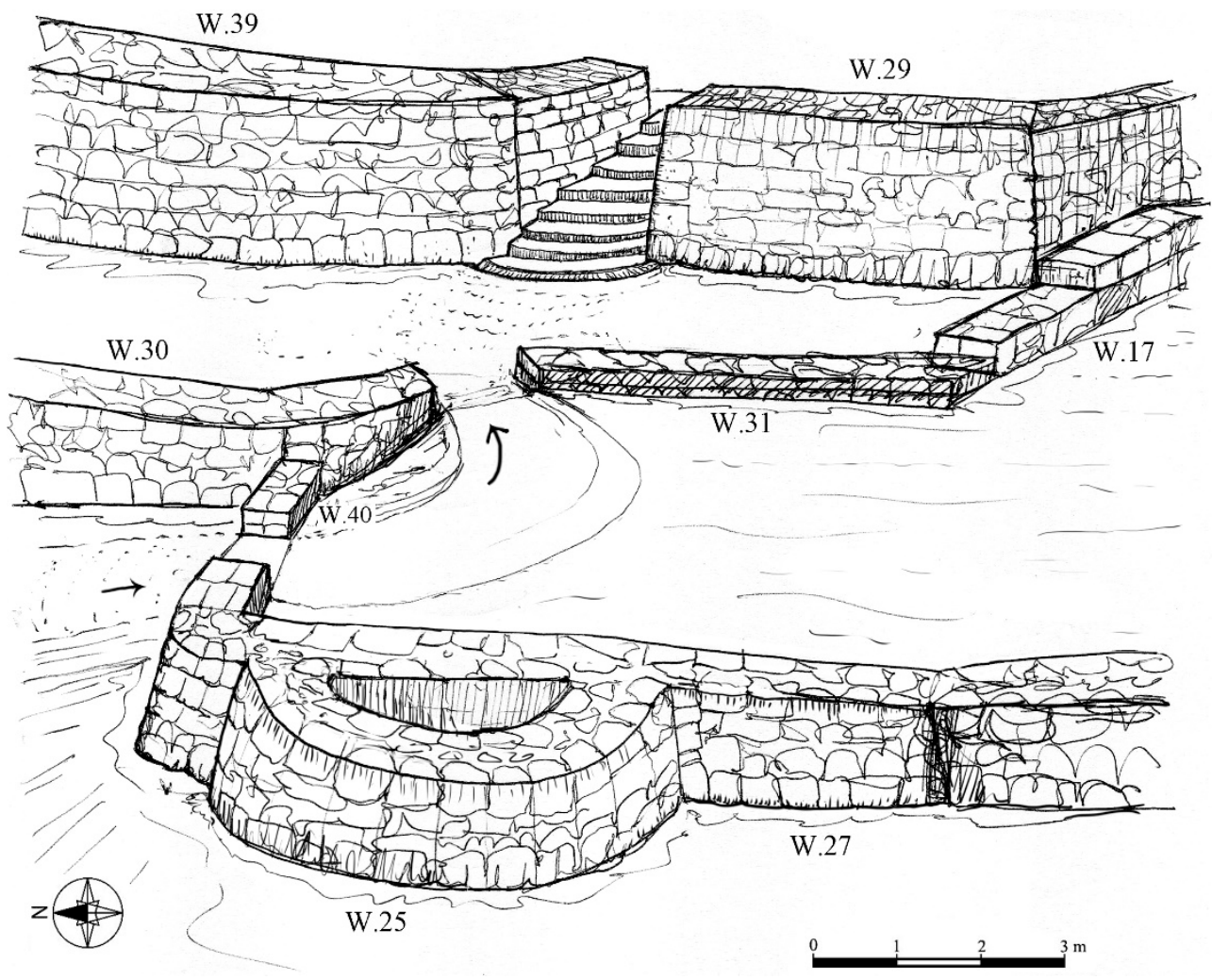

Fig. 28 - Sketch drawing illustrating the three defensive lines in Area C.

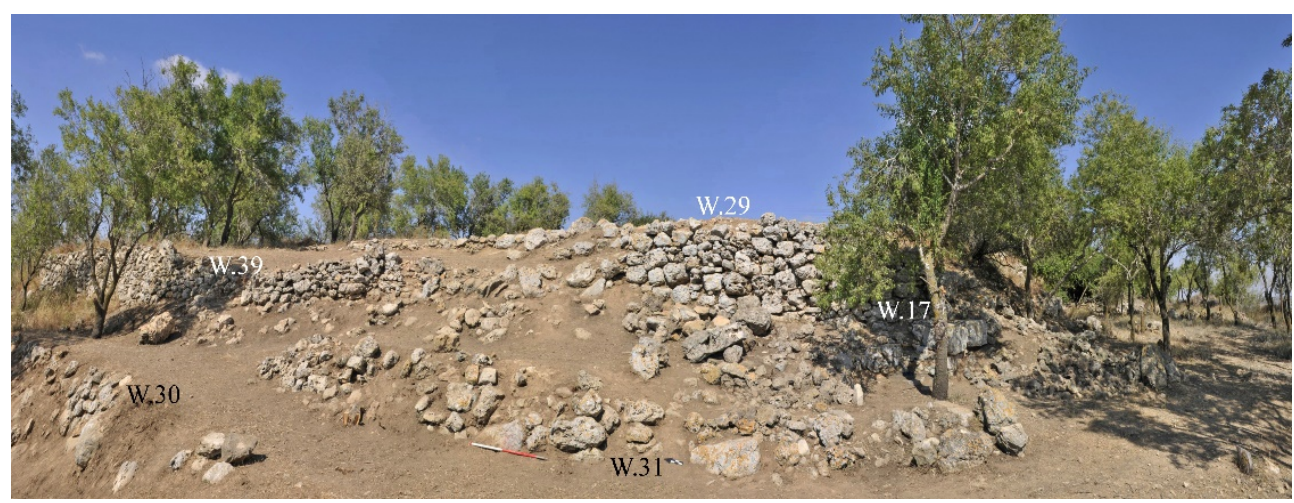

Fig. 29 - Walls W.29+W.39 and W.31+W.17, at the western edge of Acropolis in Area C, seen from west. 


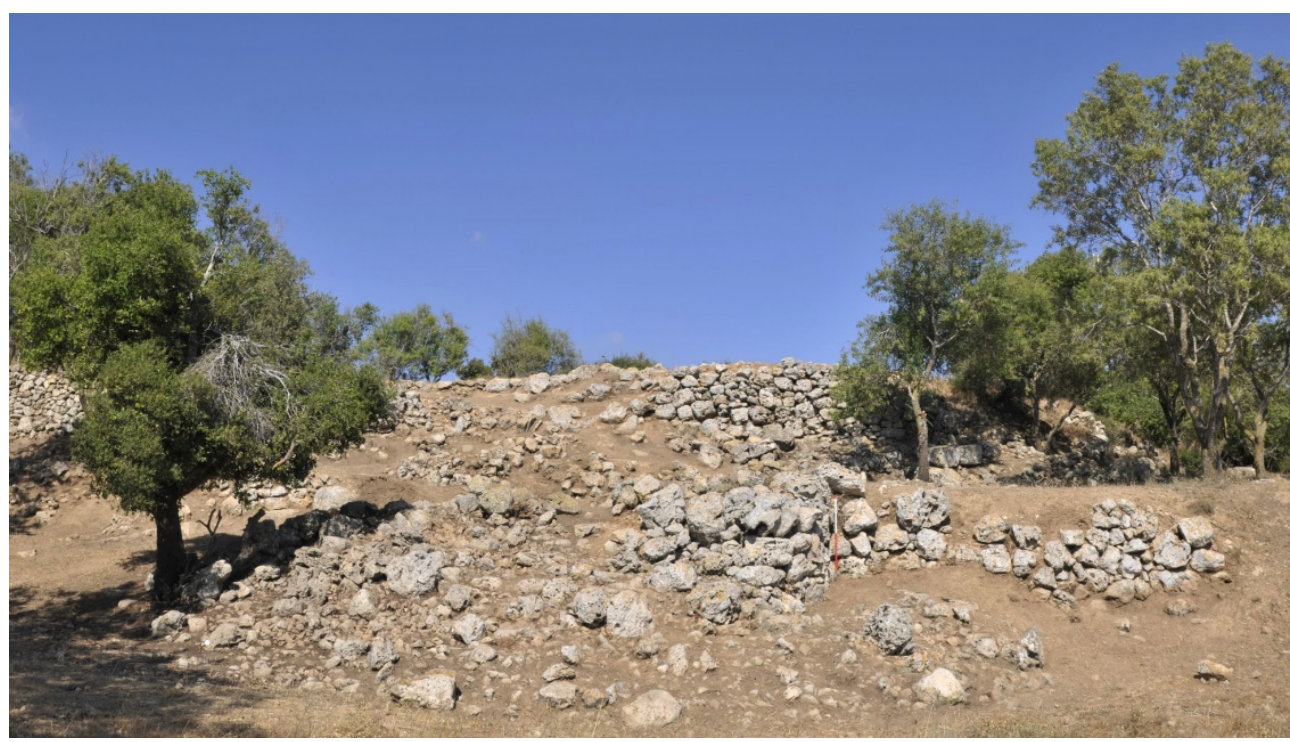

Fig. 30 - Tower T.25 in Sector XIII seen from the west.

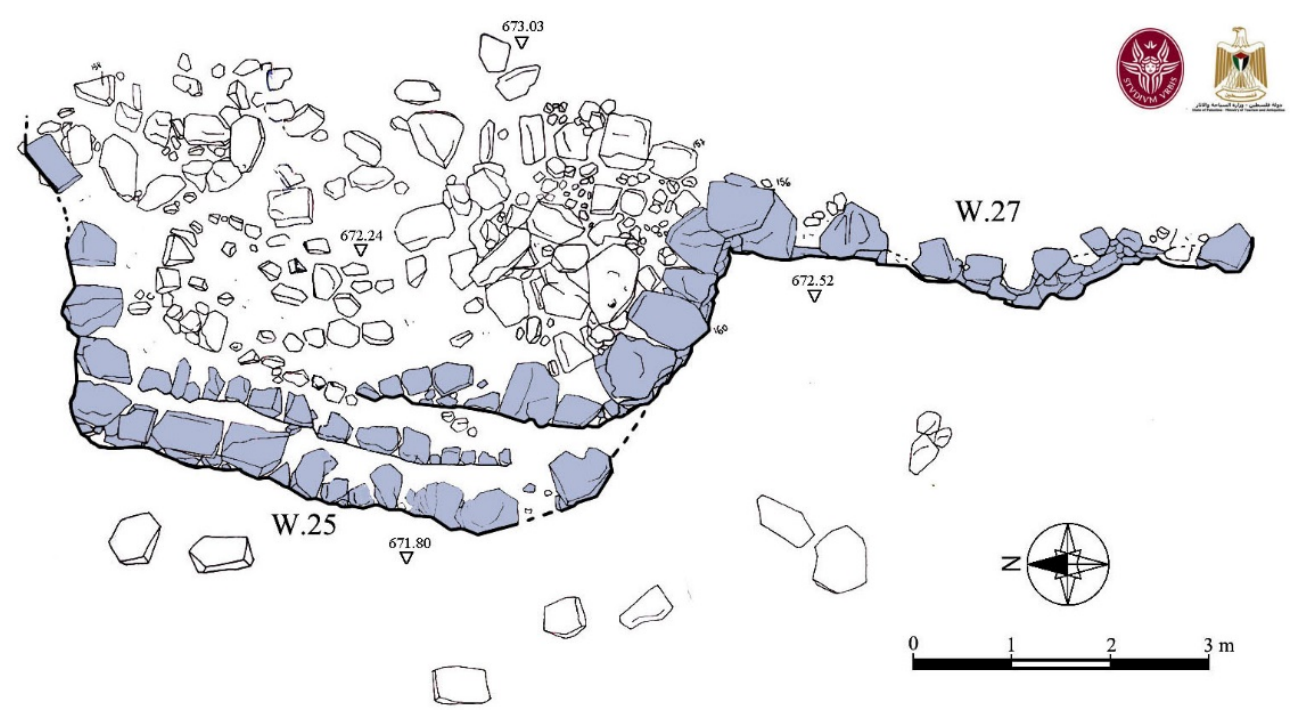

Fig. 31 - Plan of Tower T.25. 


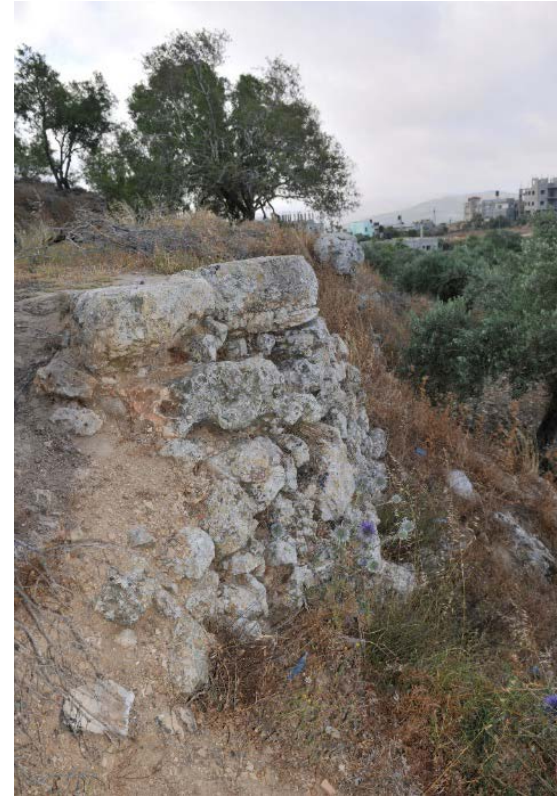

Fig. 32 - Emerging crest of Middle Bronze Age Outer Wall W.32 at the western edge of Area C, looking south.

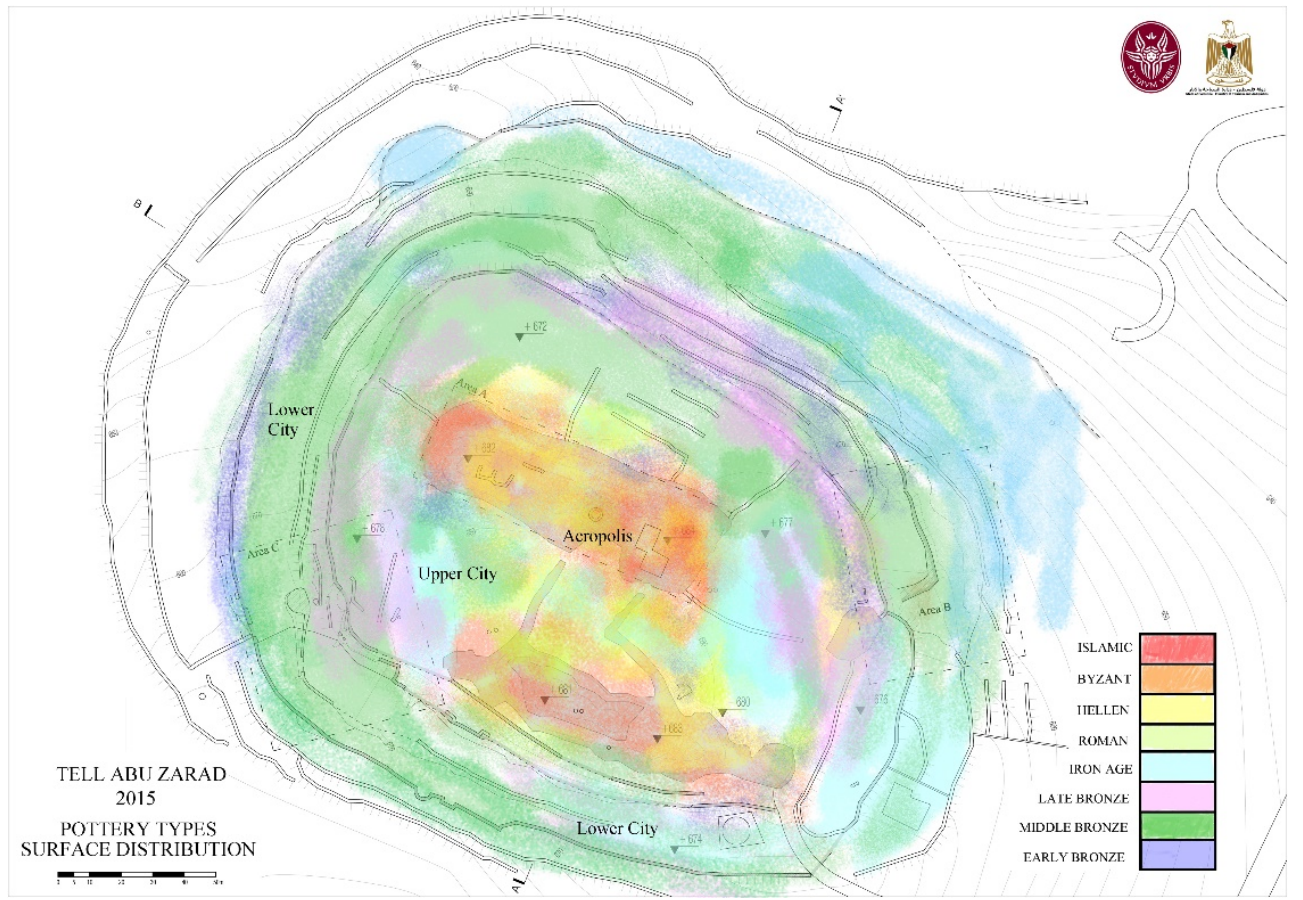

Fig. 33 - Spatial distribution of pottery types over the tell surface by periods. 


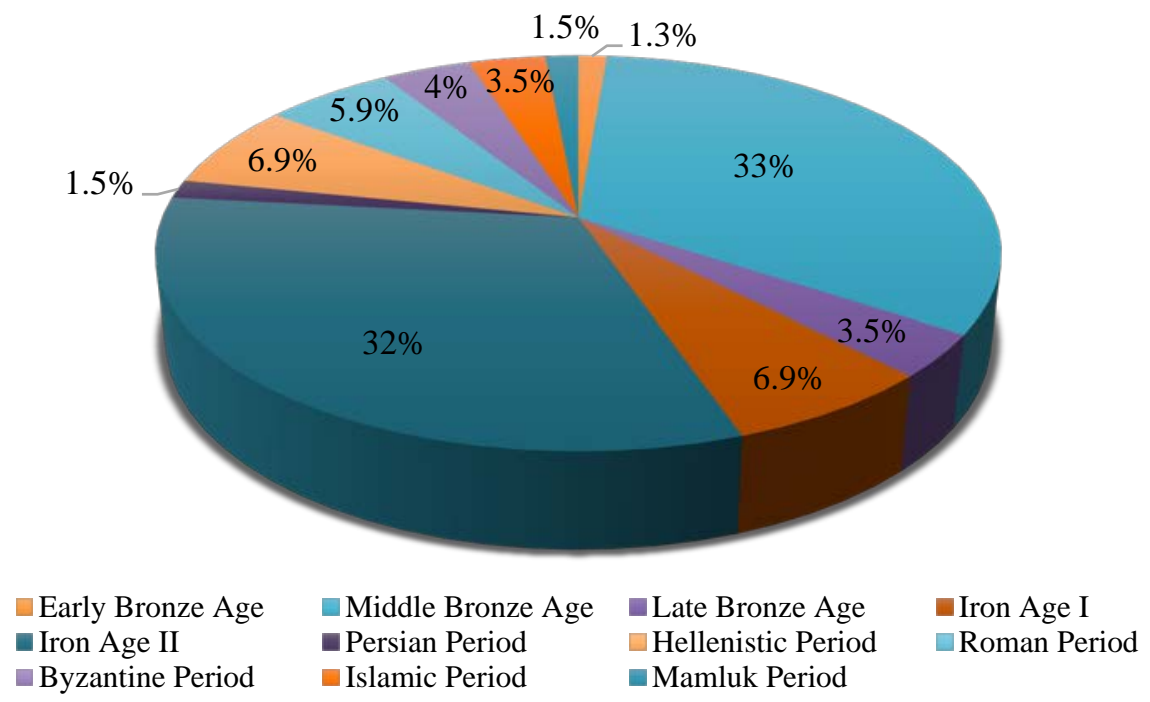

Fig. 34 - Percentage pie chart of pottery attestations in main occupational periods.
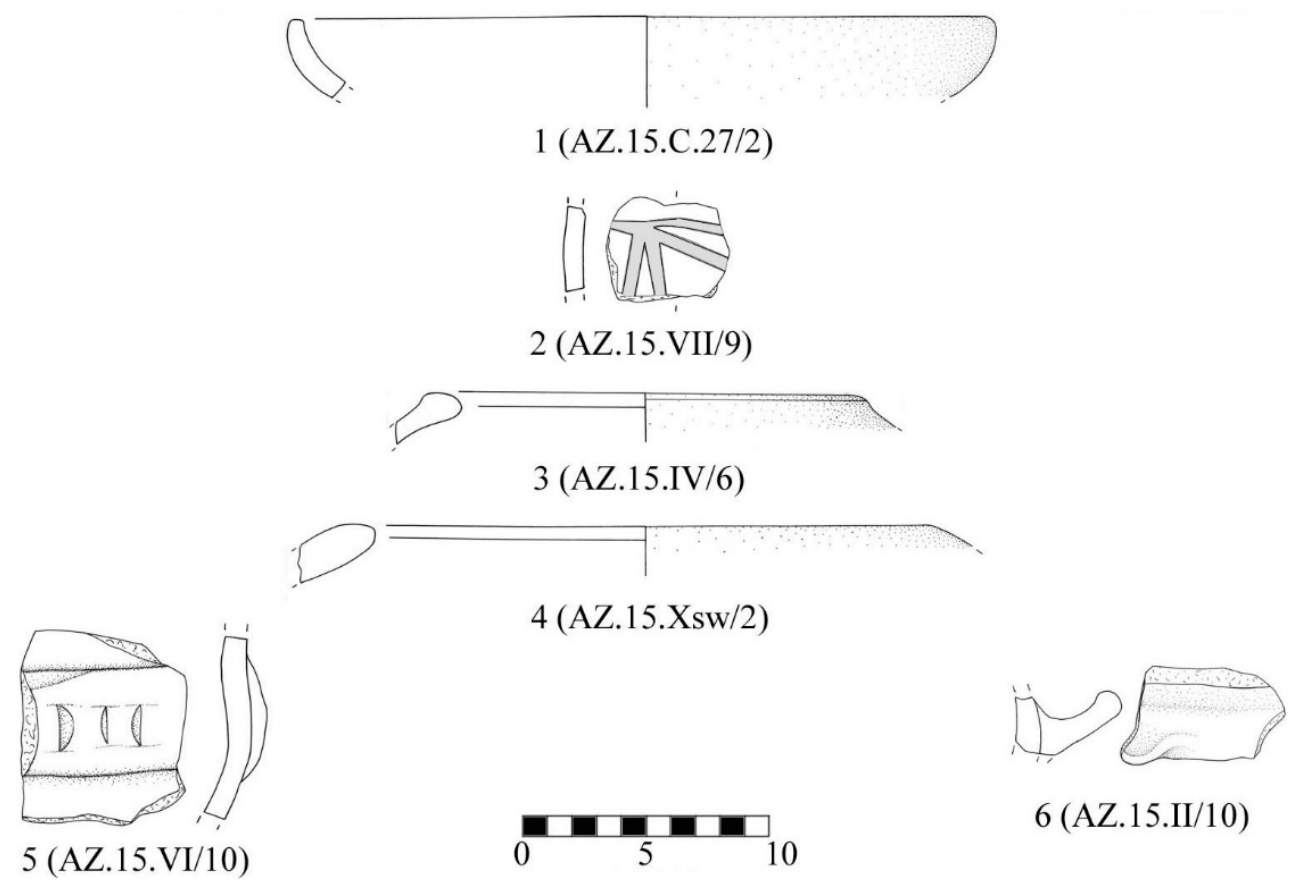

Fig. 35 - Early Bronze II-III pottery. 

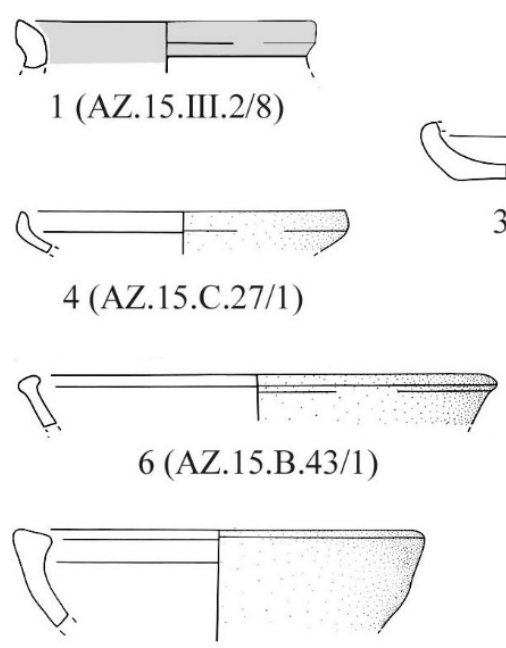

$8(\mathrm{AZ} .15 . \mathrm{III} / 23)$
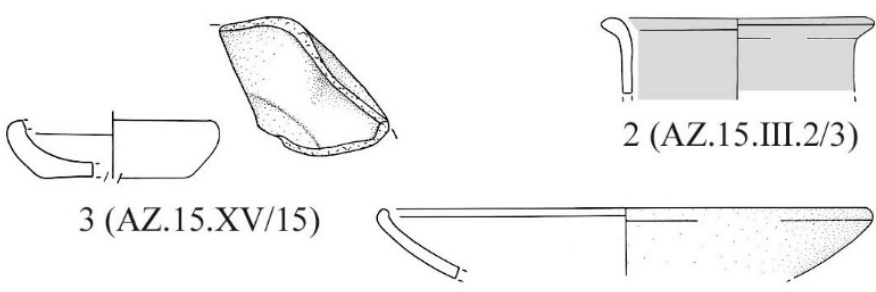

$5(\mathrm{AZ} .15 . \mathrm{XV} / 1)$

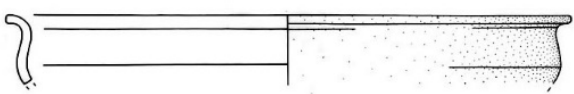

7 (AZ.15.C.0/1)

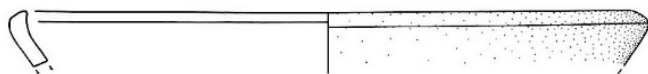

9 (AZ.15.B.15/1)

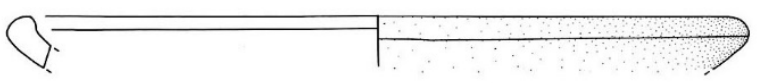

$10($ AZ.15.C.0/2)

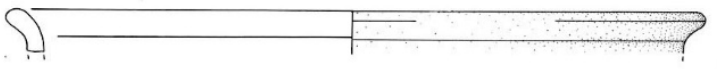

$11(\mathrm{AZ} .15 . \mathrm{III} / 14)$

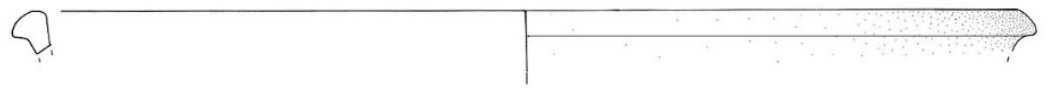

$12(\mathrm{AZ} .15 . \mathrm{V} / 1)$

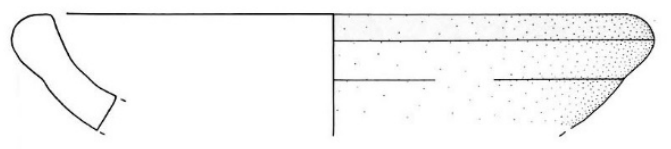

$13(\mathrm{AZ} .15 . \mathrm{XV} / 24)$

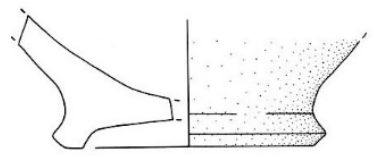

$14(\mathrm{AZ} .15 . \mathrm{XI} / 4)$

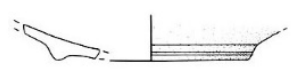

15 (AZ.15.II/5)

0

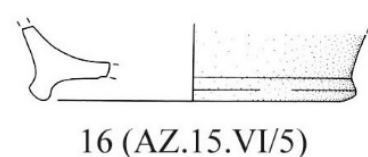

Fig. 36 - Middle Bronze II pottery. 

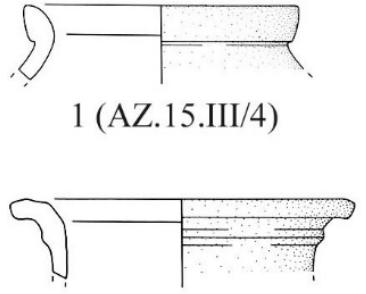

$4(\mathrm{AZ} .15 . \mathrm{XI} / 3)$

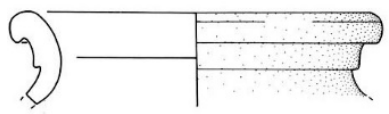

$6(\mathrm{AZ} .15 . \mathrm{XVI} / 18)$
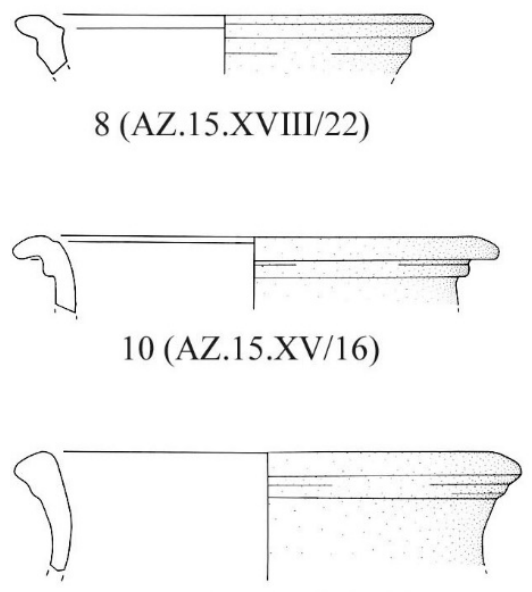

$12($ AZ.15.C.17/1)

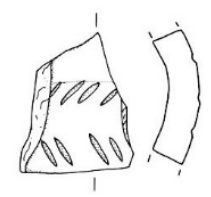

$14(\mathrm{AZ} .15 . \mathrm{XI} / 10)$
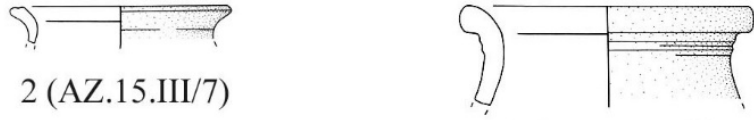

3 (AZ.15.XI/2)

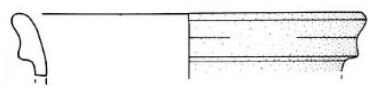

$5($ AZ.15.III.2/5)

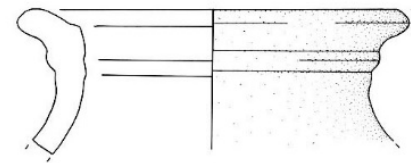

7 (AZ.15.III/12)

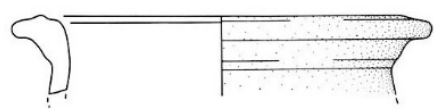

$9(\mathrm{AZ} .15 . \mathrm{B} .15 / 2)$
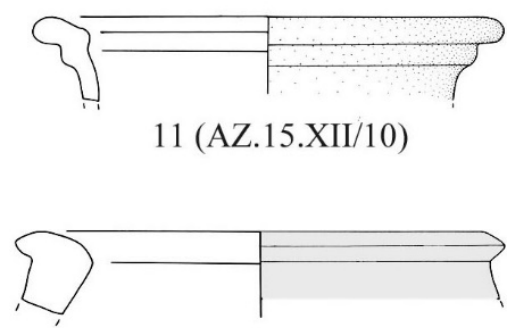

$13(\mathrm{AZ} .15 . \mathrm{VIII} / 1)$

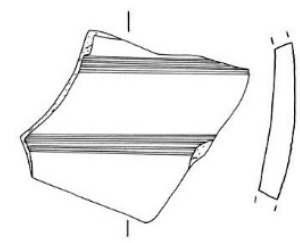

$15(\mathrm{AZ} .15 . \mathrm{XV} / 7)$

Fig. 37 - Middle Bronze II-III pottery. 

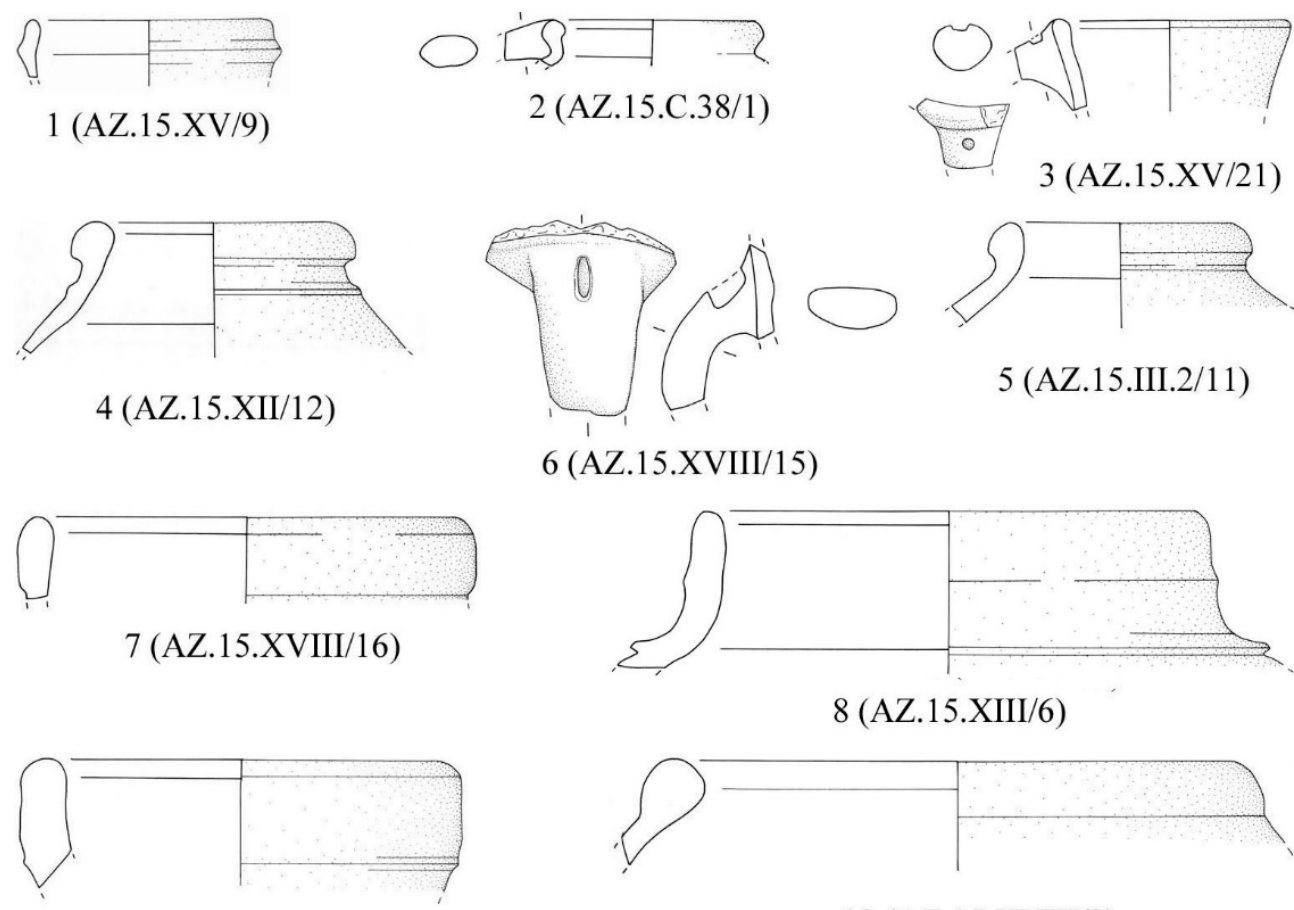

$9(\mathrm{AZ} .15 . \mathrm{XV} / 25)$
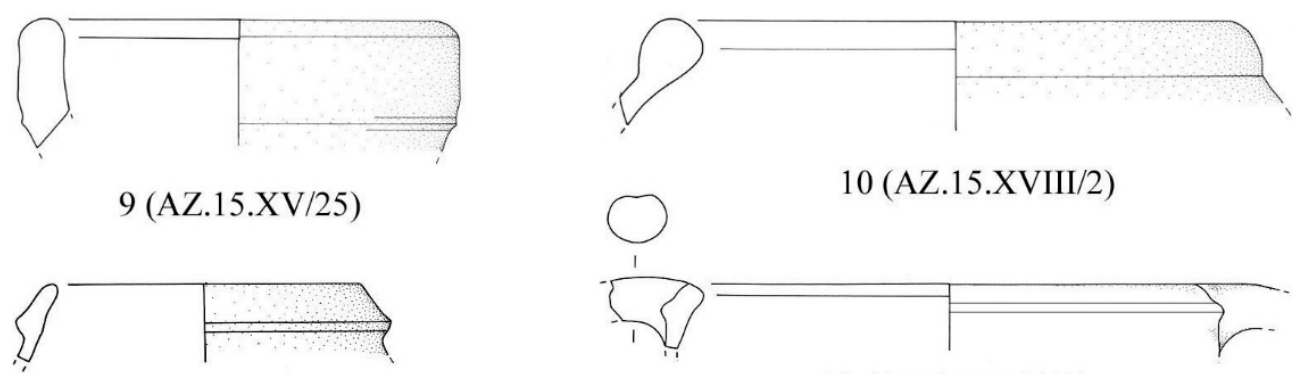

10 (AZ.15.XVIII/2)

$11($ AZ.15.B.16/1)

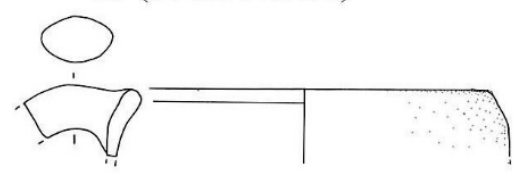

13 (AZ.15.XII/4)

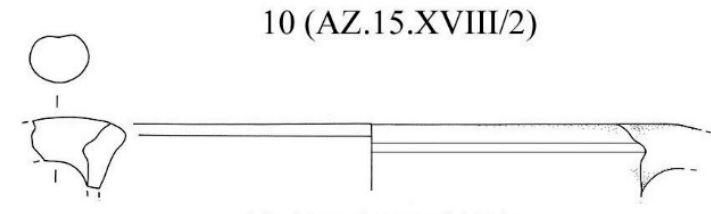

12 (AZ.15.III.2/13)

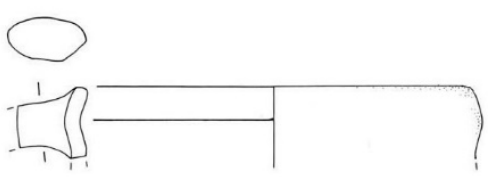

14 (AZ.15.Xsw/6)

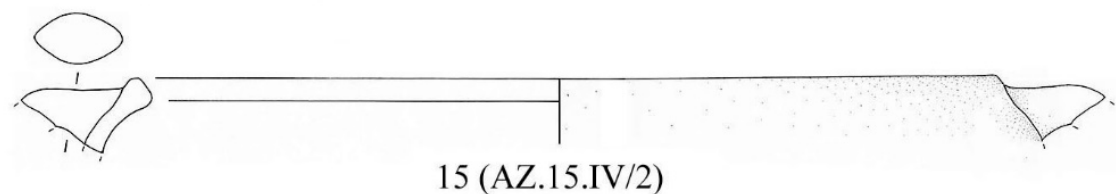

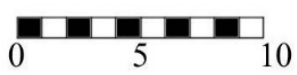

Fig. 38 - Iron Age I pottery. 


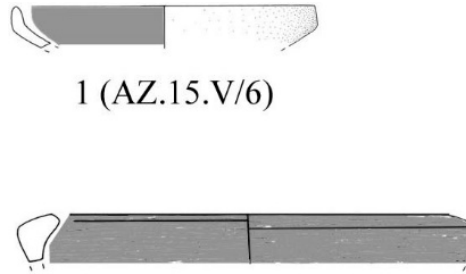

$3($ AZ.15.XVIII/18)

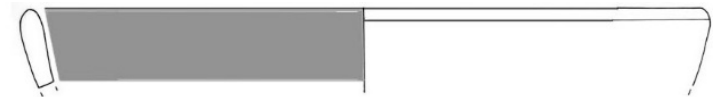

$2(\mathrm{AZ} .15 . \mathrm{Xsw} / 17)$

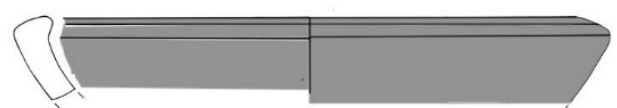

$4(\mathrm{AZ} .15 . \mathrm{Xw} / 1)$

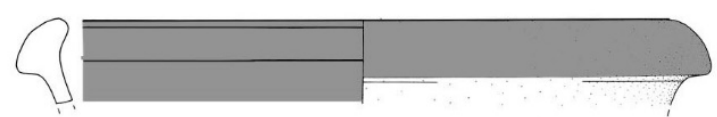

$5(\mathrm{AZ} .15 . \mathrm{Xw} / 5)$

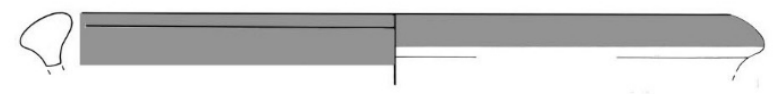

$6(\mathrm{AZ} .15 . \mathrm{XVI} / 19)$
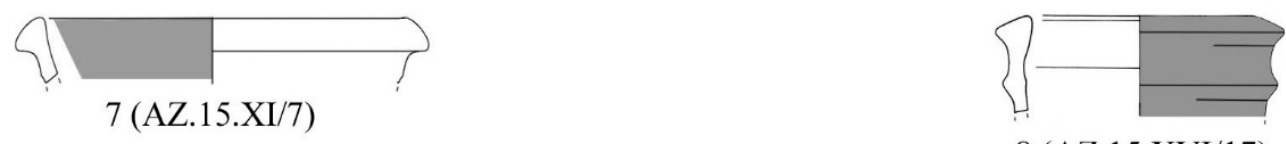

$8(\mathrm{AZ} .15 . \mathrm{XVI} / 17)$
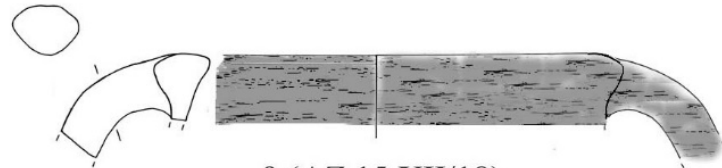

$9(\mathrm{AZ} .15 . \mathrm{XII} / 18)$

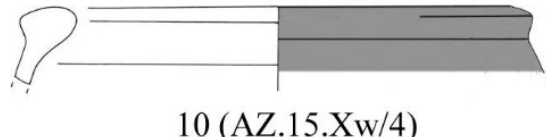

$10(\mathrm{AZ} .15 . \mathrm{Xw} / 4)$

0

Fig. 39 - Iron Age II Red Slip pottery. 


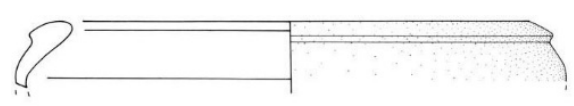

1 (AZ.15.XVIII/9)

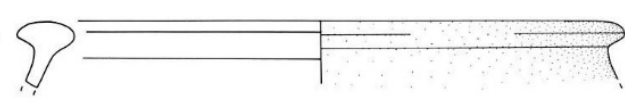

$2(\mathrm{AZ} .15 . \mathrm{XV} / 19)$

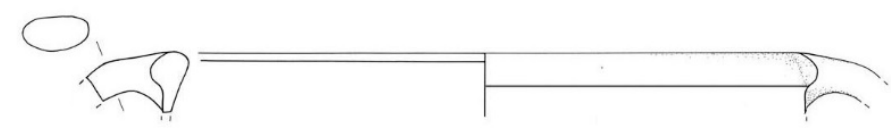

3 (AZ.15.XII/3)
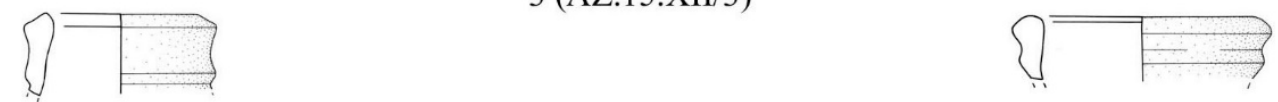

4 (AZ.15.XII/11)

5 (AZ.15.XVIII/23)

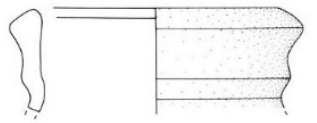

6 (AZ.15.Xw/9)

0

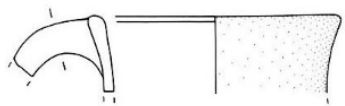

8 (AZ.15.IX/13)
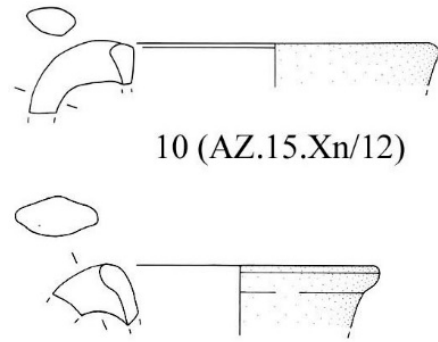

$12(\mathrm{AZ} .15 . \mathrm{XV} / 12)$

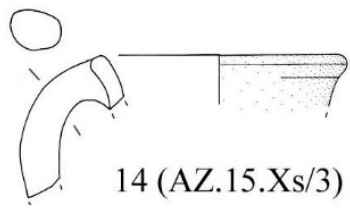

Fig. 40 - Iron Age II pottery.

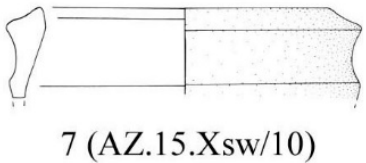

$\infty$

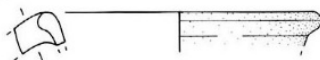

9 (AZ.15.III/18)

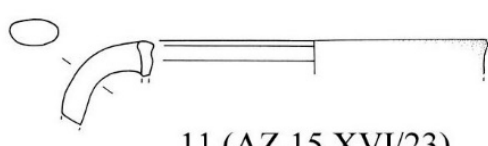

$11(\mathrm{AZ} .15 . \mathrm{XVI} / 23)$
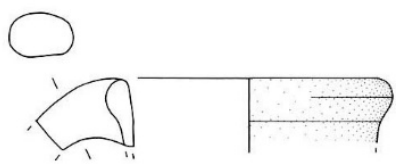

$13(\mathrm{AZ} .15 . \mathrm{V} / 5)$

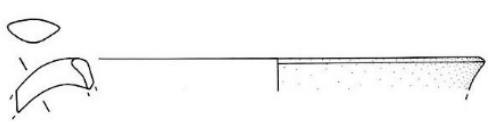

$15(\mathrm{AZ} .15 . \mathrm{VII} / 2)$

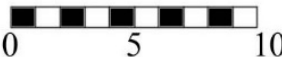

10

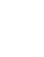




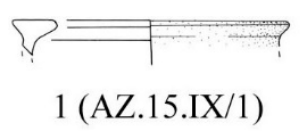

$\int_{1} 3(\mathrm{AZ} .15 . \mathrm{XIII} / 4)$

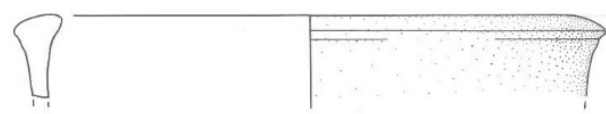

$5(\mathrm{AZ} .15 . \mathrm{VII} / 6)$

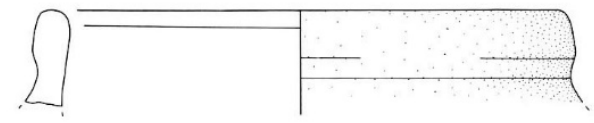

$6(\mathrm{AZ} .15 . \mathrm{Xw} / 7)$

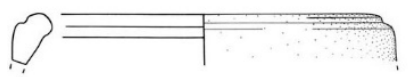

7 (AZ.15.Xn/9)

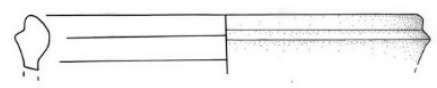

$9(\mathrm{AZ} .15 . \mathrm{VII} / 1)$

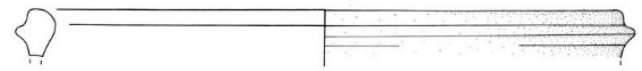

$11(\mathrm{AZ} .15 . \mathrm{III} / 17)$

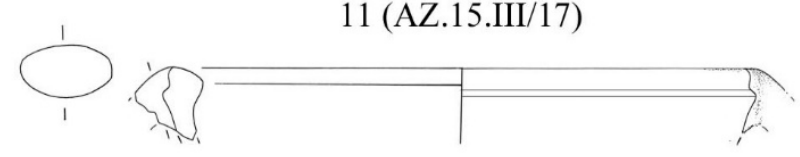

$12(\mathrm{AZ} .15 . \mathrm{II} / 4)$

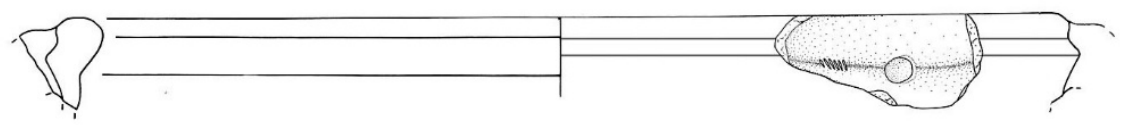

13 (AZ.15.XVIII/10)

\begin{tabular}{l|l|l|l|l}
\hline 0 & 5 &
\end{tabular}
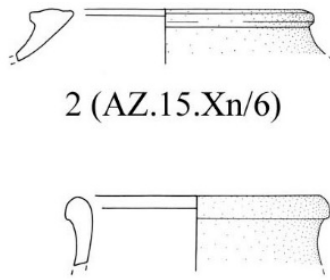

4 (AZ.15.XVIII/8) 


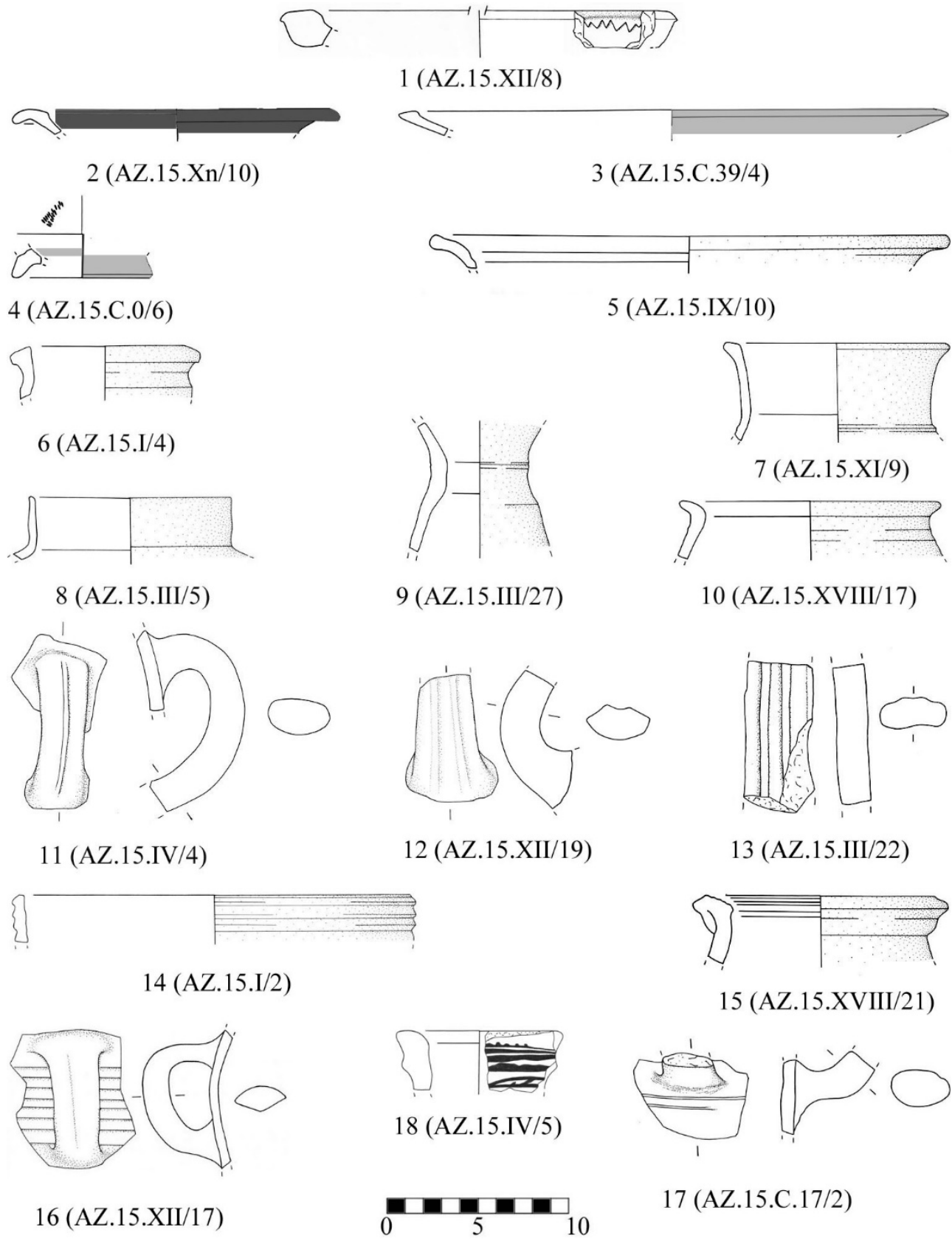

Fig. 42 - Persian, Hellenistic, Byzantine and Islamic selected pottery. 
XIX (2015) Archaeology from A to Z: Abu Zarad, an ancient town in the heartland of Palestine

\section{ARABIC ABSTRACT} في ضوء التعاون بين وزارة السياحة والآثار الفلسطينية وجامعة لاسابينز الئن روما الإيطالية، والذي بدأ منذ العام العام 1997

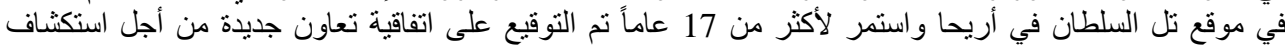

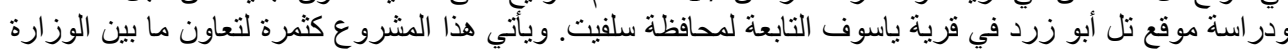

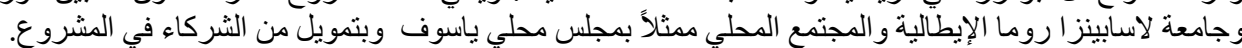

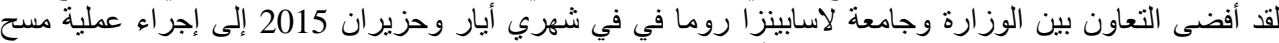

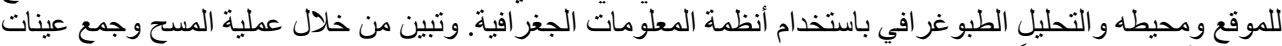

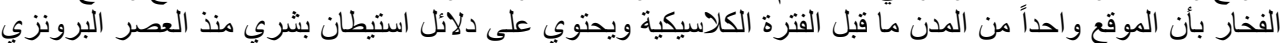

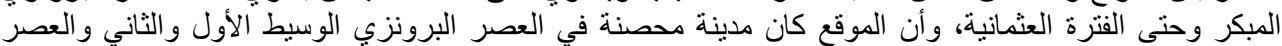
الحديدي الأول والثاني.

يقع تل أبو زرد على ظهر تلة رلئيسية ترتفع حوالي 680 م عن سطح البحر في وسط فلسطين في المنطقة الجبلية

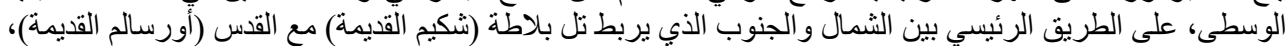

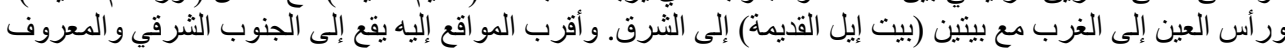

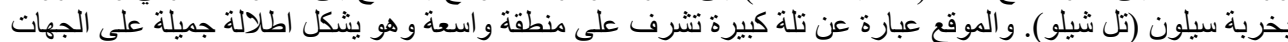

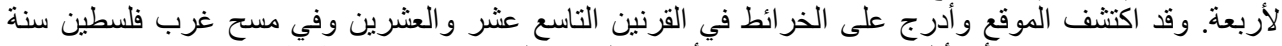

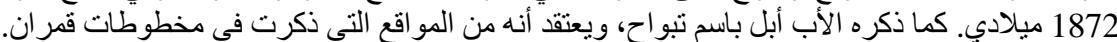

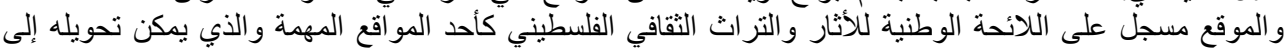
حديقة أثرية. 


\section{SOMMARIO}

DipartimENTo SCIENZE DELl'ANTICHITÀ

SEZIONE di ORIENTALISTICA

\section{VICINO ORIENTE \\ XIX - 2015}

L. Nigro - Bethlehem in the Bronze and lron Ages
in the light of recent discoveries by the Palestinian MOTA-DACH

$\checkmark$. Pisaniello - Parallel passages among Hittite-Luwian rituals:

for the restoration of $K U B 35.146$

F. Spagnoli - Una testa di sileno in bronzo da Mozia

N. Chiaren

dall Area sacra del Kothon a Mozia

G. Labisi - al-Fudayn: an Umayyad residence in Northern Jordan

P. Buzi - Early Christianity in the Fayyūm: the new contribution of archaeology

I. Materia - Preliminary notes on the ware depicted on the ceiling

of the Cappella Palatina in Palermo

S. Autiero - Indian Ocean trade:

a reassessment of the pottery find
$\left(3^{\text {rd }}\right.$ century $B C-S^{S^{t h}}$ century $\left.A D\right)$

M.M. Jamhawi - N. Al-Shakarchi - I. Al-Hashimi

Assessment of tourists' satisfaction in the downtown of Amman

SCAVI E RICERCHE

L. Nigro - C. Fiaccavento - M. Jaradat - J. Yasine

A

L. Nigro - D. Montanari - M. Ghayyada - J. Yasine

A Middle Bronze and Iron Age necropolis near Bethlehem (Palestine)

L. Nigro - G. Ripepi - I. Hamdan - J. Yasine

15 Interim Report

and valorization of archaeological heritage

R. Francia - L'archivio di tavolette del complesso B-C-H di Büyükkale

organizazione degli archivi reali ittiti. Considerazioni preliminari

V. Pisaniello - La collezione di tavolette del complesso B-C-H di Büyükkale

T. De Vincenzi - L'archivio di tavolette del complesso B-C-H
sull'acropoli di Büyükkale

Museo del Vicino Oriente, Egitto e Mediterraneo

L. Nigro - Il nuovo allestimento del Museo del Vicino Oriente,

Egitto e Mediterraneo della Sapienza

D. Montanari - Bollettino delle attività del Museo del Vicino Oriente,

Egito e Meditraneo della Sapienza, anno 2015

RECENSIONI

A. Orsingher - E. PAPPA (2013), Early Iron Age Exchange in the West:

(Ancient Near Eastern Studies Supplement Series 43)

Leuven - Paris - Walpole 2013, MA.: Peeters $\frac{1}{2}$

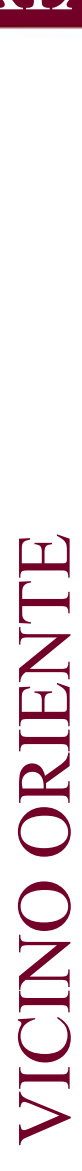

345

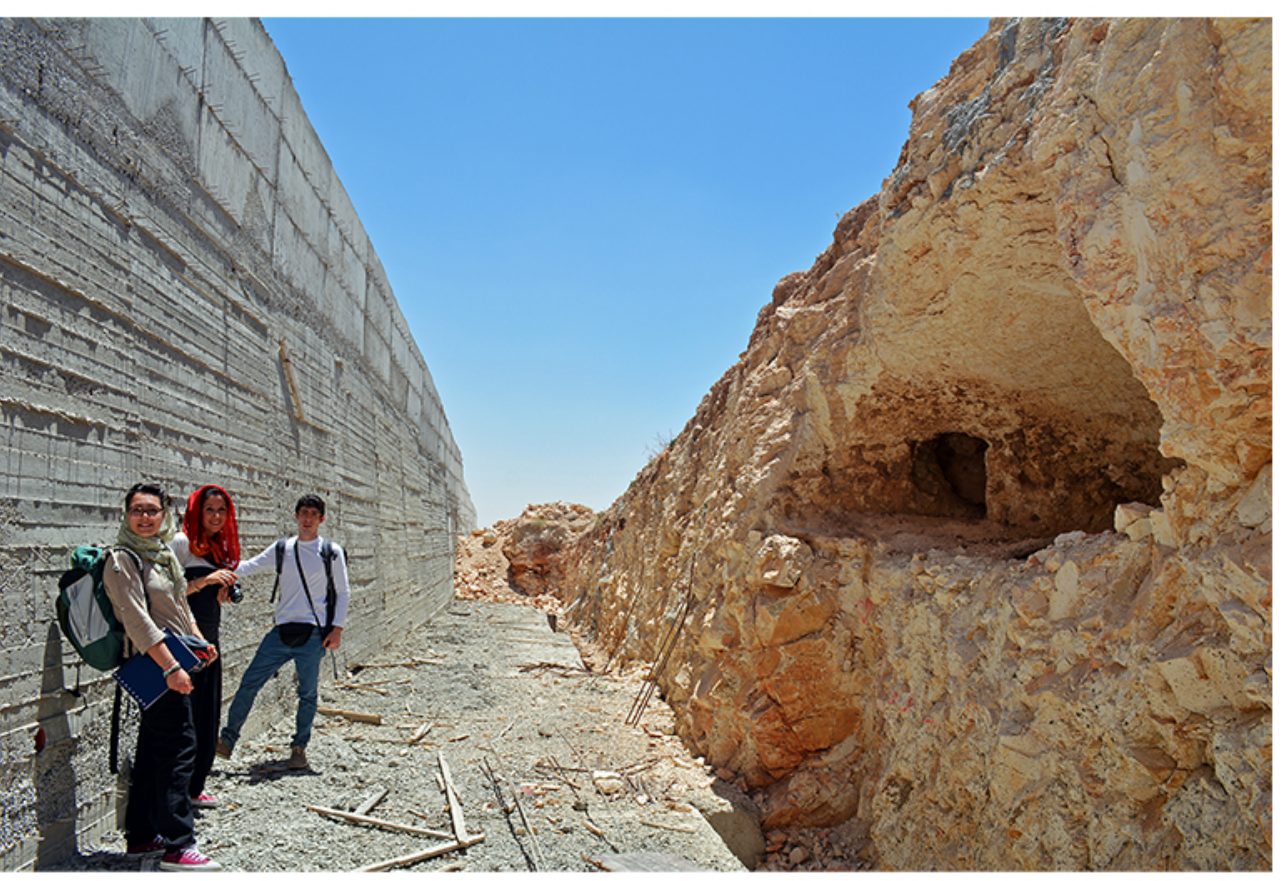

ROMA 2015 


\section{VICINO ORIENTE XIX - 2015}


VICINO ORIENTE

SAPIENZA UNIVERSITÀ DI ROMA

DIPARTIMENTO SCIENZE DELL'ANTICHITÀ

SEZIONE DI ORIENTALISTICA

Scientific Editor: Lorenzo Nigro

International Scientific Committee: Brian Rose, Frank Braemer, Mounir Fantar, Piero Bartoloni, Thomas Schaefer, Zeidan Kafafi

National Scientific Committee: Carlo Giovanni Cereti, Maria Vittoria Fontana, Sebastiano Tusa, Massimiliano Marazzi

Editorial Board: Daria Montanari, Chiara Fiaccavento

Tipografia: SK7 - Roma

ISSN 0393-0300

Rivista con comitato di referee

Journal with international referee system

www.lasapienzatojericho.it/SitoRivista/Journal/Rivista.php

In copertina: Tomba B9, necropoli di Khalet al-Jam’a (Betlemme). 
VICINO ORIENTE

SAPIENZA UNIVERSITÀ DI ROMA

DIPARTIMENTO SCIENZE DELL'ANTICHITÀ

SEZIONE DI ORIENTALISTICA

\section{SOMMARIO}

ARTICOLI

L. Nigro - Bethlehem in the Bronze and Iron Ages

in the light of recent discoveries by the Palestinian MOTA-DACH

V. Pisaniello - Parallel passages among Hittite-Luwian rituals:

for the restoration of KUB 35.146

F. Spagnoli - Una testa di sileno in bronzo da Mozia

N. Chiarenza - Una matrice per terrecotte con sileno dall'Area sacra del Kothon a Mozia

G. Labisi - al-Fudayn: an Umayyad residence in Northern Jordan

P. Buzi - Early Christianity in the Fayyūm: the new contribution of archaeology

I. Materia - Preliminary notes on the ware depicted on the ceiling

of the Cappella Palatina in Palermo

S. Autiero - Indian Ocean trade:

a reassessment of the pottery finds from a multidisciplinary point of view ( $3^{\text {rd }}$ century $B C-5^{\text {th }}$ century $\left.A D\right)$

M.M. Jamhawi - N. Al-Shakarchi - I. Al-Hashimi

Assessment of tourists' satisfaction in the downtown of Amman

SCAVI E RICERCHE

L. Nigro - C. Fiaccavento - M. Jaradat - J. Yasine Archaeology from A to Z: Abu Zarad, an ancient town in the heartland of Palestine

L. Nigro - D. Montanari - M. Ghayyada - J. Yasine

Khalet al-Jam'a. A Middle Bronze and Iron Age necropolis near Bethlehem (Palestine) 185 
VICINO ORIENTE

SAPIENZA UNIVERSITÀ DI ROMA

DIPARTIMENTO SCIENZE DELL'ANTICHITÀ

SEZIONE DI ORIENTALISTICA

L. Nigro - G. Ripepi - I. Hamdan - J. Yasine

The Jericho Oasis Archaeological Park - 2015 Interim Report.

Italian-Palestinian Cooperation for protection

and valorization of archaeological heritage

R. Francia - L'archivio di tavolette del complesso B-C-H di Büyükkale

e l'organizzazione degli archivi reali ittiti. Considerazioni preliminari

V. Pisaniello - La collezione di tavolette del complesso B-C-H di Büyükkale

T. De Vincenzi - L'archivio di tavolette del complesso B-C-H sull'acropoli di Büyükkale

Museo del Vicino ORIente, Egitto e MediterRaneo

L. Nigro - Il nuovo allestimento del Museo del Vicino Oriente,

Egitto e Mediterraneo della Sapienza

D. Montanari - Bollettino delle attività del Museo del Vicino Oriente,

Egitto e Mediterraneo della Sapienza, anno 2015

\section{RECENSIONI}

A. Orsingher - E. PAPPA (2013), Early Iron Age Exchange in the West:

Phoenicians in the Mediterranean and the Atlantic

(Ancient Near Eastern Studies Supplement Series 43),

Leuven - Paris - Walpole 2013, MA.: Peeters 